\title{
SOURCE OF INFORMATION-DRIVEN TRADING ON THE PRAGUE STOCK EXCHANGE
}

\section{František Kopřiva}
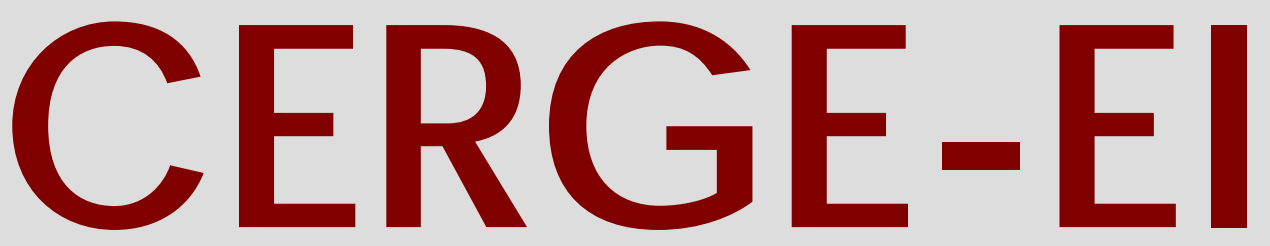

Charles University Centerfor Economic Research and Graduate Education Academy of Sciences of the Czech Republic Ec onomic s Institute 


\section{Working Paper Series 365 (ISSN 1211-3298)}

\section{Source of Information-Driven Trading on the Prague Stock Exchange}

František Kopřiva

CERGE-EI

Prague, September 2008 
ISBN 978-80-7343-165-5 (Univerzita Karlova. Centrum pro ekonomický výzkum a doktorské studium)

ISBN 978-80-7344-154-8 (Národohospodářský ústav AV ČR, v.v.i.) 


\title{
Source of Information-Driven Trading on the Prague Stock Exchange
}

\author{
František Kopřiva * \\ CERGE-EI $^{\dagger}$
}

\begin{abstract}
We focus on the extent of information-driven trading sourced from the behavior of market makers on an emerging market. We develop a methodology based on the Easley et al. (1996) model in order to estimate the extent of informed trading originating from the behavior of Czech market makers on the Prague Stock Exchange (PSE). Based on the high percentage of block trades in the years 2003-05, the market makers focusing on large customers may have a significant source of private information on the PSE. Significant differences in the behavior of market makers lead us to conclude that these differences remarkably affect the extent of information-driven trading. Under current regulation, market makers are able to protect their private information and not reveal it for a surprisingly long period of time. Our study contributes to the detection mechanisms of regulatory authorities on the emerging markets in identifying the suspicious behavior of particular market participants.
\end{abstract}

\begin{abstract}
Abstrakt
$\mathrm{V}$ naší studii se zaměřujeme na odhad rozsahu obchodování na základě neveřejných informací pramenící ze způsobu chování tvưrců trhu na malém rozvíjejícím se kapitálovém trhu. Vzhledem $\mathrm{k}$ vysokému procentu blokových obchodů $\mathrm{v}$ letech 200305 mohli tvưrci trhu zaměřující se na velké investory získat významný zdroj neveřejných informací. Rozšířením modelu Easley et al. (1996) jsme navrhli metodologii, která umožňuje analyzovat specifické chovaní market makerů na českém kapitálovém trhu a vliv tohoto chování na obchodování na základě neveřejných informací. Vzhledem $\mathrm{k}$ výrazným rozdílům $\mathrm{v}$ chování jednotlivých market makerů naše výsledky, nikoliv překvapivě, naznačují, že čeští tvưrci trhu mají významný vliv na rozsah obchodování na základě neveřejných informací. $Z$ našich výsledků dále vyplývá, že za současného regulatorního rámce jsou tvůrci trhu schopni obchodovat na základě určité informace po překvapivě dlouhé časové období. Tato studie by mohla přispět ke zlepšení detekčních mechanismů regulatorních orgánů v ČR, jelikož naše metodologie umožňuje detekci nestandartního chování jednotlivých tvůrců trhu.
\end{abstract}

JEL Classification: G14, G15, P34

Keywords: trading systems, informed trading, emerging markets

* Email: Frantisek.Kopriva@cerge-ei.cz The author would like to thank Jan Hanousek and Randall Filer for helpful comments. This research was supported by a grant from the CERGE-EI Foundation under a program of the Global Development Network and by GAČR grant (402/08/1376). The views expressed are those of the author and do not necessarily reflect the position of any of the affiliated institutions.

${ }^{\dagger}$ A joint workplace of the Center for Economic Research and Graduate Education, Charles University, and the Economics Institute of the Academy of Sciences of the Czech Republic.

Address: CERGE-EI, P.O. Box 882, Politických vězňů 7, Prague 1, 111 21, Czech Republic 


\section{INTRODUCTION}

A large number of studies deal with the issue of insider or informed trading on developed as well as emerging markets. Starting with the seminal work of Kyle (1985) various models have been developed on insider trading or informed trading and empirical studies have attempted to estimate the severity of this problem. To measure the probability of information-driven trading (PIN), Easley et al. (1996) developed a model commonly used in the literature which is based on the imbalance of buys and sells order flow. Nevertheless, Vega (2006) points out that PIN is not exclusively an insider trading measure as it also captures informed trading by investors who are particularly skillful in analyzing public news. Information-driven trading is therefore a much broader concept which includes not only the illegal insider trading, but also many other types of trading behavior and public news surprises (Vega 2006). ${ }^{1}$ Overall, PIN measures the additional cost of investing in a given market, as high PIN suggests frequent new information with an impact on the price and a high proportion of investors trading based on such information.

The extent of information-driven trading considerably affects the credibility of investors in a given financial market as it also increases the cost of acquiring the information about the good timing of the trade. As mentioned above insider trading is illegal in many countries. Nevertheless, the margin between insider and informed trading is not as obvious as it looks. Insider trading can be described as the situation where the investor is trading on some private information that is available only to a restricted number of people. There is quite a large consensus in society that the management of a company, for example, should not trade based on information about quarterly profits before their disclosure. On the other hand there are many cases where participants in the capital market trade based on private information; there is no consensus, however, whether such behavior is appropriate. ${ }^{2}$

In this paper we focus on differences in the information content of the trades of individual market makers on the Prague Stock Exchange (PSE). We analyze the behavior of Czech market makers on the most active segment in the Czech Republic - SPAD

\footnotetext{
${ }^{1}$ Contrary to the hypothesis of semi-strong efficiency which states that the public information is fully incorporated into price, the findings of Vega (2006) suggest that part of the abnormal order flow may be initiated by public news that is not easily interpreted. In other words unexpected public news may affect the PIN, and traders who are able to react promptly to it are, according to Easley et al.'s (1996) model, also informed.

${ }^{2}$ For example, the execution of large orders or the dual trading practice of some brokers or market makers.
} 
trading system. The behavior of some of the market makers on the PSE could be described as controversial. The distinctive characteristic of the Czech capital market is the dominant role of several market makers who also act as brokers. Due to the specifics of this small emerging market, every large order affects the price on the market significantly. The market makers may become informed after observing their customers' orders. Further, the lack of regulation commonly present in the developed markets ${ }^{3}$ may increase the threat of dual trading practices. Although market makers may be able to take advantage of this information by trading on their own account, such practice is probably not common since the large investors are key customers for Czech market makers; dual trading practices could affect the trust of these customers in a given market maker. Therefore, the more plausible scenario for the Czech capital market is the following. A large amount of traded volume is processed through block trades on the PSE. Because of predatory trading, institutional traders and other large investors do not want to publicly disclose their trading needs and prefer a higher degree of anonymity on the market (Economides \& Schwartz, 1995; Brunnermeier \& Pederssen, 2005). According to previous studies ${ }^{4}$, informed traders often try to hide their information and react dynamically to the behavior of other market participants and to the overall environment. The market microstructure in the Czech Republic allows such investors to negotiate the price for large block trades with the market makers; in other words, the market makers and large investors often share private information. ${ }^{5}$ Such a practice may lead to the situation where several market makers are informed. Further, only the market maker and the large investor are aware of the volume and price of the block trade prior to the execution and disclosure of the block trade. Therefore, the informed market maker may start behaving strategically to preserve this information about the large order in order to maximize his profit and to respond to the threat of predatory trading. Due to the lower competition among market makers on the Czech market, some of them are able to stay aggressively on one side of the market for relatively long time periods. That is, the dominant market makers are able to use the market to reach their desired inventory positions rather than to supply liquidity to the market. Due to the small size of emerging markets and lower competition among market

\footnotetext{
${ }^{3}$ Like, for example, the Chinese wall between brokerage and market making activities or dealership activities.

${ }^{4}$ See Admati and Pfleiderer (1988); Barclay and Warner (1993); Anand and Chakravarty (2007); Anand et al. (2005); Boehmer (2005); Huang and Stoll (1996); Lee and Yi (2001).

${ }^{5}$ For example, publicly known cases of the government selling shares of ČEZ or ČEZ buying its own shares through some market makers.
} 
makers, large block trades are a noteworthy source of private information. Market makers may therefore be a significant source of information-driven trading on small emerging markets.

To the best of our knowledge, our study is the first to analyze the extent of information-driven trading of market makers. We develop a methodology based on Easley et al.'s (1996) model to detect suspicious trading behavior of particular market makers on the PSE. By an innovative combination of PIN measure and jackknife approach we leave out trades of one particular market maker at a time from the sum of all buys and sells. We then test the hypothesis that due to some private information about a large block order the market maker behaves differently than the other market makers, using the estimates from the jackknife approach. Significant differences in the behavior of Czech market makers would lead us to conclude that, contrary to earlier studies, market makers may not only screen out the large informed traders but that on less regulated emerging markets they also strongly affect the extent of information-driven trading by sharing private information with their key large customers. Our methodology should therefore contribute to the detection mechanisms of regulatory authorities on emerging markets in order to identify the suspicious behavior of particular market participants. The paper is organized as follows: Section 2 presents the motivation and background for the present study; section 3 describes the methodology; details about the data are outlined in section 4; empirical results are discussed in section 5; and section 6 concludes.

\section{LITERATURE REVIEW}

Several studies point out that order flow obtained from customers provides an informational advantage for market makers. Literature on the information-driven trading and behavior of market makers analyzes this advantage of the market makers from several perspectives. The first stream of literature centers on the problem of dual trading. A number of papers, theoretical and empirical, deals with the problem of whether dual traders are informed or not. Most of the theoretical studies start with the assumption that dual traders are informed traders and then investigate the effect of their trading strategies (see, for example, Grossman, 1989; Roell, 1990; Fishman \& Longstaff, 1992; Chakravarty, 1994; Sarkar, 1995). 
Some empirical papers have focused on analyzing the validity of this assumption. Fishman and Longstaff (1992) developed a model of dual trading which assumes that the broker has imperfect information about his customers (whether they are informed or uninformed). Using the data for actively traded soybean futures contracts at the Chicago Board of Trade, the authors show that personal trading profits of dual trading brokers are significantly higher than those of other floor traders and that these profits are higher on days they are dual trading, suggesting that dual traders are informed. Chakravarty and Li (2003a) estimate a simultaneous equation model with a binary endogenous variable (the decision whether to trade on the broker's own account) and a trading profit variable. The main difference between their approach and the study of Fishman and Longstaff (1992) is that they isolate the abnormal trading profit associated with the dual trading from the overall trading profit. Chakravarty and Li (2003a) use for their analysis the transaction records of futures contracts at the Chicago Mercantile Exchange (CME) and their results suggest that dual traders are uninformed. In another work, Chakravarty and Li (2003b) examine if dual traders are informed by regressing their own account trades on inventory control, liquidity supply and on variables capturing information, derived from observing their customers' orders. Again, they conclude that the dual trader is an uninformed trader trading primarily for liquidity provision and inventory rebalancing. The authors acknowledge that the difference between their study and the study of Fishman and Longstaff (1992) may stem not just from the different approach taken but also due to differences in data and time periods. Namely, the study of Fishman and Longstaff (1992) was based on data from a period just before the FBI launched a federal investigation into fraudulent trading practices on the Chicago futures exchanges.

On a more general level, several papers focus on the overall information advantage of market makers, dealers or brokers rather than on a particular practice like dual trading. Madhavan and Panchapagesan (2000) develop and test a model based on the opening procedures on the NYSE with a strategic market maker setting the opening price after observing the order flow. They point out that the market maker significantly facilitates price discovery - the opening price set by the specialist is more efficient than the price that would prevail in a pure auction with only public orders. Hasbrouck and Sofianos (1993) show that market makers are not only able to affect the price but also to generate short term profits. The authors focus on the trading behavior of NYSE specialists. The long-term profits of specialists on the NYSE are not significantly different from zero. 
However, by analyzing inventory adjustment, price determination, and trading profits they conclude that the specialists are able to generate short-term trade profits, mostly as a consequence of the bid-ask spread. Further, although the specialists are capable of rapidly adjusting their positions they usually opt for adjustment lags of days or weeks. Therefore, the authors' results suggest that the requirements and monitoring of the NYSE play an important role in the behavior of specialists since, despite their informational advantage, they do not misuse it to generate profits. Kurov and Lasser (2004) address a similar issue by assuming that market microstructure and regulation are key features affecting the response to private information sourcing from the order flow. Through an analysis of the trades of CME locals on the E-mini markets, they conclude that the exchange locals are informed traders with an informational advantage sourced primarily from the obtained order flow.

Nevertheless, the dealers or market makers may gain an advantage over the other participants in the market not only from the order flow but also from other privileges. Focusing on the pure limit order market, Wang and Chae (2003) found a strong positive correlation between dealers' weekly trades and weekly returns, mainly for large dealers. Their results imply that the large dealers on the Taiwan Stock Exchange are acting as informed traders rather than as liquidity suppliers. However, only brokers on the market are able to view the order flow of their customers. Therefore, the informational advantage of the dealers on the market likely originates from their privileged position of direct access to the electronic exchange without any trading fees or trading delays.

So far, the literature suggests that market makers or dealers may anticipate private information from the order flow. Nevertheless, studies analyzing the behavior of traders suggest that the profit-maximizing informed trader will protect his information using stealth trading practices. Barclay and Warner (1993) were the first to propose the stealth trading hypothesis: that informed traders are splitting their orders and using medium-sized trades to avoid detection. They argue that due to the lack of anonymity on the market for large orders, also known as an upstairs market, informed traders may secure a more favorable price by breaking up their large orders into medium-sized trades; the authors thus expect that most of the stock's cumulative price change should take place on the medium-size trades. Barclay and Warner (1993) find empirical evidence for their hypothesis using a sample of NYSE stocks from 1981 to 1984. 
Several studies provide further empirical evidence for the stealth trading hypothesis (Anand \& Chakravarty, 2007; Anand et.al., 2005; Chakravarty, 2001). Chakravarty (2001), analyzing the sample of NYSE stocks data, confirms the results of Barclay and Warner (1993) and further points out that the primary source of the stealth trading are institutional investors. Anand and Chakravarty (2007) test the stealth trading hypothesis in the options market. They show that informed traders use medium-sized trades in high leverage and high volume options but prefer small-sized trades in higher leverage but lower volume options. Anand et al.'s (2005) results support the notion that informed traders dynamically update their behavior according to market structure and to the behavior of other participants in the capital market. In their empirical analysis of audit trail data from the NYSE they find that informed (institutional) traders use market orders more often in the first half of the trading day. However, they also frequently use limit orders acting as liquidity suppliers in the second half of the day. Chakravarty et al. (2005) provide further evidence that informed traders dynamically react to the conditions and behavior of the market on the example of the Australian Stock Exchange. They conclude that, like the US market, informed traders tend to break up their orders into medium-sized and, surprisingly, small-sized trades. Further, their results suggest that the informed traders tend to use smaller-sized trades when selling stocks that incur price decreases. Nevertheless, contrary to previous research, they do not find any evidence that the institutional investors are better informed. Previous studies focused on markets with market makers affirm that the medium-sized orders are the most informed. Charoenwong and Jenwittayaroje (2007), on the other hand, examine stealth trading on a pure limit order market (Stock Exchange of Thailand) and conclude that informed traders are using largersized trades compared to the dealership markets.

The above-mentioned studies suggest that the behavior of informed traders differs according to the market microstructure and that the market makers are important participants in the market in that they are able to recognize the informed traders. Several studies examine the ability of market makers to identify informed traders and its effect on the probability of information-driven trading. For instance, in comparing trades on the NYSE and NASDAQ, Garfinkel and Nimalendran (2003) suggest that the spread is larger on insider trading days, leading to the conclusion that the NYSE as a less anonymous market has a lower extent of informed trading. Heidl and Huang (2002) support Garfinkel and Nimalendran's (2003) results by analyzing the change in the extent of information- 
driven trading due to a change in the listing of the stock. They conclude that a change in listing from dealership to auction market (NASDAQ to NYSE or AMEX) leads to a significant decrease in the extent of information-driven trading. Therefore, either the specialist on the NYSE has a greater ability to identify informed traders, or the informed investors prefer to trade on a market with a higher degree of anonymity. Grammig et al. (2001) similarly analyze the difference in the extent of information-driven trading between dealership and auction markets. Using data from non-anonymous floor trading on the Frankfurt Stock Exchange and the anonymous electronic trading system IBIS (replaced by XETRA in 1997), Grammig et al. (2001) suggest that informed traders prefer to execute their orders in an anonymous environment. They conclude that a greater degree of anonymity is associated with a higher probability of information-driven trading, which is significantly lower on the Frankfurt Stock Exchange. A similar issue address Huang (2002) and Barclay et al. (2003) by focusing on ECN networks on NASDAQ. They show that the anonymous ECN networks attract more informed traders mainly during the high volume trading periods and that the ECN trades' price impact is significantly higher than the impact of the trades of the NASDAQ market makers. Also, Lee and Yi (2001) investigate how informed investors choose the market they trade on. The authors analyze the relation of information-driven trading and the size of the trades on the options and stock markets. They argue that small informed investors prefer to trade through the options market. However, in the case of large informed traders, the extent of informationdriven trading is higher on the NYSE than on the Chicago Board Options Exchange.

Analyzing a theoretical model of an anonymous trading floor with a nonanonymous upstairs market for block transactions, Seppi (1990) points out that only uninformed traders will trade on the upstairs market. Smith et al. (2000) support Seppi's (1990) model empirically by analyzing the upstairs market for large orders on the Toronto Stock Exchange (TSE). The structure of the TSE is such that it does not allow an investor to select the upstairs or downstairs market for execution. All orders go first to the market maker on the upstairs market who then decides whether to react to them or to send the order downstairs. Nevertheless, the key feature of the TSE is the rule imposed on the market maker to execute the orders on terms at least as favorable as those available on the downstairs market at the time the order is received. Market makers therefore submit most of their orders immediately downstairs. Smith et al. (2000) conclude that due to the screening of the market makers, they do not trade with informed traders and send their 
orders directly downstairs, resulting in more information content of trades in the downstairs market. The non-anonymous upstairs market, therefore, significantly improves the liquidity of the large liquidity orders, which also lowers the cost to process such large orders. But it is the regulation of the upstairs market that is most important on the Toronto Stock Exchange. The rule of granting a price at least as good as on the downstairs market may increase the transparency of large orders.

All of the above-mentioned studies assume that market makers use the information from the order flow either to act contrary to their customers or to screen out the informed traders. Yet, the results of Hanousek and Podpiera $(2002,2004)$ support our hypothesis that market makers may share private information with their key large customers. Hanousek and Podpiera (2002) estimated the extent of informed trading on the Czech capital market in the blue chips segment of the PSE, using for their analysis Easley et al.'s (1996) model which views the information as lasting for one day and estimating the information content of order flow from order imbalance (difference between the number of buy and sell orders over the day). Their results show that the probability of informed trading is considerably higher in the Czech market than in developed markets, on average 0.32. However, Hanousek and Podpiera (2004) present more intriguing results - despite the many improvements in regulation and increased trading volume, the extent of information-driven trading was nearly the same for the years 1999 and 2002. They emphasize that the extent of informed trading was about the same for shares of Česká spořitelna and Erste bank. Based on the fact that these shares have very little in common except the PSE market makers, one could question to what extent the market makers on the PSE affect the probability of informed trading. ${ }^{6}$

\section{Methodology}

\subsection{EASLEY ET AL. (1996) MODEL}

Our model is based on the framework developed by Easley et al. (1996). In their model, three types of agents exist on the market - uninformed (noisy) traders, informed traders, and market makers. Trading is divided into $n$ separate trading days. Before each day an information event may occur. An information event is defined as the occurrence of

\footnotetext{
${ }^{6}$ In 2000, Česká spořitelna was sold to the Austrian banking house Erste Bank. Erste Bank, already listed in Vienna, started dual listing on PSE in October 2002.
} 
a signal $s$ about the value of an asset. ${ }^{7}$ The probability that a signal occurs is $\alpha$, and if a signal occurs, it takes on two possible values: low with probability $\delta$ and high with probability $1-\delta .{ }^{8}$ If a signal occurs, some fraction of the traders receives the signal. If no signal occurs, all traders stay uninformed. All participants are familiar with the structure of the market and see all the trades with identification of the market maker which was on the one side of the trade. The uninformed traders and market makers learn during the day and update their beliefs about the occurrence and type of the signal. After each trading day the information is revealed to all participants of the market. The arrival rates of traders follow Poisson processes with arrival rate $\varepsilon$ for uninformed traders and $\mu$ for informed traders. ${ }^{9}$ Liquidity traders buy or sell shares of the asset for reasons that are exogenous to the model. However, informed traders trade only when they see some signal; if they receive good news (the current asset price is below the liquidation value of the asset) they buy the stock, and if they receive bad news they sell the stock. The probability that a bad news day occurs is $\alpha \delta$ and the arrival rates of buyers and sellers are $\varepsilon$ and $\varepsilon+\mu$ respectively. The good news day occurs with probability $\alpha(1-\delta)$ and the arrival rates of buyers and sellers are $\varepsilon^{+} \mu$ and $\varepsilon$. The no event day occurs with probability $1-\alpha$ and the arrival rate of both buyers and sellers is $\varepsilon$. Therefore the probability of observing a given number of buys and sells can be expressed as

$$
\begin{aligned}
L((B, S) \mid \theta)= & (1-\alpha) * e^{-\varepsilon T} \frac{(\varepsilon T)^{B}}{B !} e^{-\varepsilon T} \frac{(\varepsilon T)^{S}}{S !} \\
& +\alpha \delta^{*} e^{-\varepsilon T} \frac{(\varepsilon T)^{B}}{B !} e^{-(\mu+\varepsilon) T} \frac{((\mu+\varepsilon) T)^{S}}{S !} \\
& +\alpha(1-\delta) * e^{-(\mu+\varepsilon) T} \frac{((\mu+\varepsilon) T)^{B}}{B !} e^{-\varepsilon T} \frac{(\varepsilon T)^{S}}{S !}
\end{aligned}
$$

where $S$ is number of sells, $B$ number of buys. The first part of expression (3.1) denotes a no event day, the second part a bad event day and the third part a good event day. The assumption of the model states that the days are independent and therefore the probability of observing a series of days with a given sum of buys and sells for each day is a product of the probability for individual days.

\footnotetext{
${ }^{7}$ See Figure 1 - tree diagram of the trading day.

${ }^{8}$ In the case of a bad signal the value of the asset is $\underline{V}$, for a good signal $\bar{V}$, and for no signal unchanged.

${ }^{9}$ We are assuming that the arrival rates of uninformed buyers and sellers are the same, as Easley et al. (1996) did not find significant difference between them.
} 


$$
L\left(B_{1}, S_{1}, \ldots, B_{I}, S_{I} \mid \theta\right)=\prod_{i=1}^{I} L\left(\left(B_{i}, S_{i}\right) \mid \theta\right)
$$

The parameter $\theta=(\alpha, \delta, \varepsilon, \mu)$ is then estimated using the maximum likelihood method. The probability of information-driven trading is the chance that a market maker will trade with an informed trader and therefore can be computed as a ratio of the arrival rate of informed traders and the arrival rate of all traders:

$$
P I N=\frac{\alpha \mu}{\alpha \mu+2 \varepsilon}
$$

This is actually a conditional probability of an information-driven trade given the occurrence of a trade at the beginning of a trading day. The numerator is therefore a product of the probability of an information event times the arrival rate of informed traders. The denominator is then the probability of an occurrence of a trade, which is the probability of an incoming informed trader plus the probability of an incoming uninformed buyer and seller.

\subsection{LARGE BLOCK TRADES AND INFORMED MARKET MAKERS}

In the original model there is only one type of market maker, who is seen as an uninformed agent ready to buy or sell the asset at their posted prices. In contrast to the original model, here we consider two types of market makers. We assume not only uninformed market makers, similar as in Easley et al.'s (1996) model, but also informed market makers who may have information about a large order. In other words, suppose that there is other information affecting the price of an asset - information about a large order that is independent of the above-mentioned private signal of the informed investors and that lasts for several trading days. Only one informed market maker has private information about this large order coming on the market from one of his clients. The large order consists of a random volume of shares and random length $\mathrm{K}$ of trading days, which can be the number of trading days till the deadline when the client would like to have the trade processed ${ }^{10}$. The uninformed market makers do not know about the large order or the occurrence of the signal and therefore post prices for sell and buy. The informed market maker on the other hand will trade actively only on the buy or sell side according to his private information.

\footnotetext{
${ }^{10}$ Even though block trades must be reported within 5 minutes in opening session and within 60 minutes in closed session the behavior of market makers suggests that they are aware of the block trade in advance.
} 
Further, to minimize the impact on the price, the large orders are usually processed in such a way that the market maker and the large investor decide to settle on the block trade, i.e., the market maker will accumulate the shares and then use the block trade with his client. Therefore the market maker has incentives to act strategically in trying to choose the optimal timing of several trades to process the whole large order at the best possible price. He is not, however, trying to manipulate the price or engage in any illegal practice. In addition, we assume that there is only one informed market maker in a given time period. If more than one market maker receives the large order and if the market makers do not act in consonance with each other, the order will be revealed to the whole market and the new value of the asset will be revealed immediately by the competitive behavior of two or more informed market makers ${ }^{11}$. If the market maker is informed, we assume that he does not set quotes which would reveal his information about the order immediately to everybody. In the case of a large buy order, for example, the informed market maker would just try to be in the best quote ${ }^{12}-$ he would post his quotes for buys more actively and therefore end up with the best quote with a higher probability than the uninformed market maker. Although the other market makers may anticipate that the market maker is informed, they will still be unaware of the size and limit price of the large order. Therefore, even though they know that some new information exists, the price will not reach the new value of the asset ${ }^{13}$ immediately, as the other market makers will not post better quotes than the informed market maker facing the risk that they are above or under the new price. On the other hand, in the case of a large sell order the informed market makers will post their quotes such that they avoid ending up with the best quote on the buy side. Another viewpoint is that the market makers without private information about the large order would try to avoid risky unbalanced positions and so post quotes such that they would have balanced inventories. In contrast, the informed market makers may, contingent on their information, venture riskier positions from the perspective of uninformed market makers and therefore may actively quote only buys or sells. The uninformed market makers generate profit from the trading fees and spread, while, the informed market maker is generating profit also from proprietary trading. They will likely

\footnotetext{
${ }^{11}$ Given the low number of market makers, we assume that the competition of two or more informed market makers would reveal information about a large order relatively fast according to time $\mathrm{K}$.

${ }^{12}$ Pair of the best buy and best sell quote from all quotes of market makers.

${ }^{13}$ The new value of the asset also consists of the information about the large order.
} 
end up with an unbalanced number of buys and sells after a trading day or series of trading days.

To estimate the extent of information-driven trading due to large orders we first run estimations for the whole sum of buys and sells. Further, to estimate the probability of informed trading originating from large orders or some other private information of market makers we propose a procedure to estimate PIN with and without the trades of informed market makers: we exclude each market maker's trades from the sum of buys and sell step by step and estimate the model. Having all the parameters $\theta_{i}=\left(\alpha_{i}, \delta_{i}, \varepsilon_{i}, \mu_{i}\right)$ estimated for each market maker, we then test whether the PIN using estimated parameters $\theta=(\alpha, \delta, \varepsilon, \mu)$ and PIN without considering the trades of a given market maker are significantly different. Both estimators of PIN have an asymptotically normal distribution and the estimators are positively correlated. Using the test of the equality of the mean of two normal distributions and neglecting the correlation would imply an even more significant difference than the p-value suggests. Having identified the informed market makers we can estimate the effect of large orders on the probability of informed-driven trading:

$$
\operatorname{PIMM}(t)=\left|\frac{\alpha \mu}{\alpha \mu+2 \varepsilon}-\frac{\alpha_{i} \mu_{i}}{\alpha_{i} \mu_{i}+2 \varepsilon_{i}}\right|
$$

where $\theta=(\alpha, \delta, \varepsilon, \mu)$ are the estimated parameters $\theta=(\alpha, \delta, \varepsilon, \mu)$ from the classic Easley et al. (1996) model using the sum of all buys and sells for each day and $\theta_{i}=\left(\alpha_{i}, \delta_{i}, \varepsilon_{i}, \mu_{i}\right)$ are the estimated parameters using the sum of all buys and sells for each day without the trades of a given identified informed market maker. The extent of information-driven trading sourced from the behavior of an informed market maker is therefore the difference between the probability of informed trading with and without the trades of the informed market maker. 


\section{DATA}

For our analysis, we employ intra-day data of trades from the PSE's SPAD trading system for all stocks traded during the time period 1.1.2003 to 30.9.2006, publicly available online. ${ }^{14}$ SPAD was established in 1998 to increase the liquidity of the market. The system is designed as a dealer market with at least three market makers for each stock who are required to quote ask and bid prices for a standardized number of shares with limited maximum possible spread for each stock. If a given quote is the best available on the market, the particular market maker is obliged to trade on the posted quote for buy or sell. Each trading day is divided into two phases - open and close. The actual trading occurs during the open phase of the system, which lasts from 9.15 a.m. to 4.00 p.m. each trading day. Each trade record in our database consists of security identification, date, time, type of the trade, price, and for the standard SPAD trades also the identification of the market maker who traded it. ${ }^{15}$ We utilize data on all SPAD trades during the sample time period. The sample period consists of 945 trading days and we focus on all 10 companies traded during the period. ${ }^{16}$ Only 6 of the 10 were traded during the whole period - two banks: Erste Bank (EB) and Komerční banka (KB); a petrochemical company: Unipetrol (UNI); an electricity generator: C̆EZ; a telecommunication company: Telefonica $\mathrm{O} 2^{17}(\mathrm{O} 2)$; and a cigarette producer: Philip Morris (PM). Another telecommunication company: České Radiokomunikace (CRA) was removed from the market in September 2004. One IPO of Zentiva (ZEN) was introduced to the market in June 2004. In February 2005 a construction company ORCO already listed in Paris started dual listing on PSE and in June 2005 a media company CME, already traded on NASDAQ for over 10 years, entered the PSE.

A key advantage to our dataset is that we are able identify not only whether the given trade was buyer or seller initiated but also which market maker was on the mandatory side of the trade. We have eleven market makers in our sample period -6 brokerage firms: ATLANTIK finanční trhy, a.s., BH Securities a.s., CA IB Securities, a.s., Fio, burzovní společnost, a.s., Patria Finance, a.s., WOOD \& Company Financial Services, a.s. and 5 banks: Česká spořitelna, a.s., HVB Bank Czech Republic a.s.,

\footnotetext{
${ }^{14}$ www.akcie.cz, last accessed (30.6.2007)

${ }^{15} \mathrm{We}$ are also able to identify the cross trades - those trades conducted between the inventory of the market maker and the market maker's client.

${ }^{16}$ Market capitalization and overall traded volumes are given in Table 1.

17 former Český Telecom
} 
Raiffeisenbank a.s., ING Bank N.V., Komerční banka, a.s. ${ }^{18}$ The market makers differ in their specialization on different types of customers - retail vs. large. However, none of the eleven market makers on SPAD had a significantly higher market share in any of the analyzed stocks. In our sample each traded stock has at least 6 market makers with comparable market shares. Table 2 shows that the maximum market share reached 25.56 percent for MM 7. The average number of trades during a day differs widely among the stocks during the sample period. However, the average for each stock was moderately increasing and did not change considerably for most of the analyzed time periods. Newly introduced stocks attracted the attention of investors quite quickly and the activity of these new blue chips on the PSE was almost immediately comparable to that of the already established stocks. Also, based on the average number of trades, two important events changed the trading of the two new blue chips ORCO and CME: On $30^{\text {th }}$ November 2005 Morgan Stanley included CME in its MSCI index, resulting in increased attention of mainly foreign investors. Similarly, on $4^{\text {th }}$ January 2006 Citigroup analysts increased the target price for ORCO and attracted the concern of a large number of investors. As there are only limited possibilities to take short positions on the PSE, the attraction of many buyers radically changed the trading of ORCO.

Not only the average number of trades, but also the average percentage of block trades differs notably among the stocks. Our model assumes that block trades are a powerful source of information for some market makers and the data seem to bear out this assumption. Block trades are defined by a limit set by the PSE; this limit is considerably larger than the market capitalization of the trading lots in SPAD. Under current regulation every block trade has to be registered within 5 minutes during the open phase (9:15-16:00) and within 60 minutes during the close phase. Yet, there have been important changes in the regulation of the financial market in recent years with respect to the block trades and overall activities of brokerage firms. The Czech Securities Commission ceased to operate on $31^{\text {st }}$ March 2006 and all its responsibilities were transferred to the $\breve{C} N B$ on $1^{\text {st }}$ April 2006. The main difference we see in the regulation is the requirement of the $\breve{C} \mathrm{NB}$ to report dealings book to the regulatory authority. As indicated in Table 3, a large percentage of volume traded on SPAD was done through block trades. Even though there is a remarkable decrease in the percentage of block trades in 2006, caused probably by the

\footnotetext{
${ }^{18}$ In order to preserve impartiality we replaced all the names of the market makers in our database with codes MM1 to MM11.
} 
increased regulation of market makers by the obligation to report their activities to the regulatory authority, we still observe striking differences in the volume of block trades among the stocks in our sample during the years 2003-05. The remarkably high percentages of block trades for some stocks (e.g. O2, CRA, KB) together with the huge drop in 2006 suggest that large investors and market makers focused on large customers are dynamically responding to the regulation of the market. Further, the high percentage in the years 2003-05 would seem to indicate that those market makers focused on large customers had also used standard SPAD trades to gather the stocks in order to execute the block trades. Such market makers are actually informed traders, and hence the block trades may have been a significant source of private information on the PSE.

SPAD was introduced to increase liquidity on the PSE. However, due to the size of the trading lots, only medium and large investors actually trade in the system. The trading lots varied quite a lot during our sample period since the prices of some stocks grew. ${ }^{19}$ The value of the trading lot varied from 0.64 million CZK for ORCO to 5.49 million for ČEZ. The change of the lot size may have impact on the extent of information-driven trading since, in line with the Easley et al. (1996) model, informed traders are more likely trading larger volumes. Regarding the increase of retail investors in the Czech Republic, therefore, lowering the lot size may attract more uninformed investors as on SPAD the fees are notably lower.

During the sample period two privatizations of UNI and $\mathrm{O} 2$ took place. The second privatization of UNI (the first one failed) officially started on $6^{\text {th }}$ November 2003. Firms had till $20^{\text {th }}$ November 2003 to show preliminary interest. On $12^{\text {th }}$ January 2004 PKN Orlen of Poland, MOL of Hungary, British-Dutch group Royal Dutch/Shell, Penta of Slovakia, and KazMunaiGaz of Kazakhstan completed the preliminary registration and offered a tender price. Only three of them, PKN Orlen, MOL and Royal Dutch/Shell, made the final offer on $23^{\text {rd }}$ April 2004. The government then sold its 63 percent stake in UNI to PKN Orlen for 11.3 billion CZK (480 million USD) in May 2004.

The privatization of $\mathrm{O} 2$ was even more complicated, as the Czech government had already made several attempts to sell its share in O2 and in 1995 sold 27 percent to TelSource. However, after several negotiations on further privatization of $\mathrm{O} 2$, the government finally decided to choose another strategic partner or to sell the remaining 51 percent share through the market. In December 2003 TelSource sold through the book

${ }^{19}$ See Table 4. 
building 27 percent of $\mathrm{O} 2$ for $255 \mathrm{CZK}$ per share. According to the managers of the transaction (Credit Suisse First Boston, Morgan Stanley) the demand significantly exceeded the supply. In 2004 O2 bought 49 percent of Eurotel (the Czech mobile operator). The final privatization of $\mathrm{O} 2$ started on $3^{\text {rd }}$ February 2005 when Telefónica, Belgacom, Swisscom Blackstone, CVC/Providence/France Telecom and Tiscali/PPF/J\&T/In Way made preliminary offers. However, by $30^{\text {th }}$ March 2005 only three of them had made a final offer. Telefónica surprised analysts and for 51.1 percent offered 82.623 billion CZK (i.e. 502 CZK per share). Swisscom was willing to pay 79.2 billion CZK and Belgacom 67.5 billion CZK. Therefore, as price was the only criterion, the Czech government sold its 51.1 percent share in O2 to Telefónica in April 2005.

\section{RESULTS}

There are significant differences in the intra-day trading periods on the Czech capital market. New information arrives to the market before the morning session and again in the afternoon when news from the US capital market is known. Since only a minority of trades takes place between 12:00 p.m. and 14:00 p.m. and even these are generally done by automation, we do not consider them in our analysis. We chose to divide each day into two parts - morning session 9:15 a.m. to 12:00 p.m.; and the afternoon session, 14:00 p.m. to 16:00 p.m. Given that the trading behavior of investors as well as market makers follows a very different pattern during the morning and afternoon session, we estimated the extent of information-driven trading for both sessions separately.

Given the long time span of our dataset and consistent with the assumption of stationarity of Poisson processes in the model, we decided first to run the rolling window of 90 trading days through our sample period and for each window estimate the extent of information-driven trading. We believe that the 90 trading day window strikes an optimal balance between the assumption of stationarity and reasonable length according to the precision of estimates. ${ }^{20}$ Although during some rolling windows the assumption of stationarity was violated, this procedure gave us a first clue to the behavior of market makers during our sample period. The resulting graphs are presented in Figures $2 \mathrm{a}, 2 \mathrm{~b}$ and

\footnotetext{
${ }^{20}$ We have run the estimation also for shorter rolling windows, but our results suggest that the 90 day rolling window still satisfies the assumptions of the model since the results are similar for the shorter rolling windows, as shown in Figures 10-13.
} 
$2 \mathrm{c}$ at the end of the paper. Based on these results we proceeded to focus on particular stocks for which our initial estimations of 90 day rolling windows suggested different behavior of particular market makers. Table 5 illustrates the results of tests on the time periods we chose to focus on after the initial insight based on the rolling window estimations. Overall, our results suggest that during our sample period there were several market makers that behaved differently than the rest of the market makers on the PSE. This, however, does not necessarily imply that the market maker is an insider; he may be processing a large foreign order or engaging in dual trading practice, which is not illegal in the Czech Republic. Nevertheless, rejecting the null hypothesis of equality of the estimates means that the market maker has a considerable imbalance between his mandatory sells and buys, and that his behavior differs from the behavior of other market makers during the particular time period.

In the second column of Table 5 is the tested time period for the particular stock. Although the choice of focus on particular stocks, market makers, and time periods was based solely on the results of rolling windows PIN estimations, most of the time periods tested corresponded to important events for particular stocks. Further, our results are in accord with the assumption of only one informed market maker. In nearly all cases there was only one market maker whose behavior differed noticeably from the remaining market makers. The first row of Table 5 lists the results for CRA. CRA was removed from the market in September 2004, but the decision to remove it had been made in 2003. Our results - that the MM4 behaved differently than other market makers in the second half of the year 2003 - may suggest that he cooperated with some large informed customer who had some private information about the buyout of CRA.

In the case of $\mathrm{O} 2$ several important events took place during the years 2003-2005. Our results suggest that some of the investors had better information than the rest of the market and traded on this information ahead of time. Particularly, there was markedly different behavior of one informed market maker for the years 2004-05. The results for ČEZ, KB and PM confirm the perception that the high percentage of block trades (around $30 \%$ ) may have had a significant impact on the behavior of some market makers.

Our results suggest that even though the participants in the market are aware of the different behavior of several market makers, they are not able to compete with them due to the superior information sourced, for example, from information about a large order. As mentioned above, our test is based on the comparison of estimates using the whole sum of 
buys and sells and of estimates using just the sum of buys and sells without a particular market maker. Even though the market participants are able to see the sum of buys and sells they are not able to completely reveal the information about the large order. The informed market maker is therefore able to protect his private information about such an order.

Contrary to earlier studies, our trade data consist of precise information on whether the trade is a mandatory buy or a mandatory sell. ${ }^{21}$ Boehmer et al. (2007) point out that using only predicted instead of actual information on the type of the trade (buyer or sellerinitiated) leads to downward-biased PIN estimates. The magnitude of the bias is related to the security's trading intensity. This may partly explain why our results differ from those of Hanousek and Podpiera (2004), since they used data for the whole day and estimated whether the trade was buyer or seller-initiated using Lee and Ready (1991) methodology. Hanousek and Podpiera (2004) concluded that during the years 1999-2002 there were no visible improvements in the extent of information-driven trading. Yet, our results suggest that all the blue chips experienced a considerable decrease in the PIN during the years 2003-2006. Dividing the trading day into morning and afternoon sessions reflects more accurately the specifics of the small emerging market. Further, possibly due to strengthening the regulation of market makers by introducing the liability to report regularly detailed information about their activities, the extent of information-driven trading decreased markedly during our sample period.

We additionally focused on the effect of trading lot change on trading behavior. Changing the lot size may affect the extent of information-driven trading as informed traders are more likely trading larger volumes. The estimation and test results are summarized in Table 6; most of the changes in lot size affected the extent of informationdriven trading since the decreases in lot size attracted the trading volume of uninformed investors. A most interesting result is the case of the changing lot size for UNI. The change attracted many new investors, yet, because the extent of information-driven trading changed significantly only in the morning session, we can assume that they were from Europe or the Czech Republic.

\footnotetext{
${ }^{21}$ If the quote is the best available on the market and if some investor reacts to it, the market maker is obliged to enter his instruction so that the trade can be executed.
} 


\section{CONCLuSion}

In this paper we have analyzed the behavior of market makers and their ability to maintain private information about large orders. We found significant differences in behavior among market makers on the Prague Stock Exchange. Market makers have indeed a dominant role and have enough power not only to affect the price in the short term, but if we take into the account large orders, they may also affect the price over a surprisingly long time period. Although other market participants may be aware that some of the market makers possess private information about the value of the asset, they are not able to reveal the whole of that information. Further, our analysis suggests that important changes like decreasing the volume of a trading lot may affect the extent of informationdriven trading. In this respect our methodology should contribute to the detection mechanisms of regulatory authorities on emerging markets in identifying the suspicious behavior of particular market participants.

Although our data suggest that market makers hold a very strong position on the PSE, determining the optimal policy from the regulatory point of view is not so straightforward. Market makers should be protected to be able to execute large orders without the threat of predatory trading. Yet the current practices of market makers incur losses to the minority investors, who are not able to buy or sell the stocks at the price fully reflecting all the relevant information. Further, under current regulation market makers are able to protect and not completely reveal their private information for a surprisingly long period of time, leading to the perception that further regulation (already common on the developed markets) may help increase the credibility of investors in the market. 


\section{REFERENCES}

Admati, A. R., Pfleiderer, P. (1988). A theory of intraday patterns: Volume and price variability. Review of Financial Studies, 1, 3-40.

Anand, A., Chakravarty, S. (2007). Stealth-trading in options market. Journal of Financial and Quantitative Analysis, 42, 167-188.

Anand, A., Chakravarty, S., Martell, T. (2005). Empirical evidence on the evolution of liquidity: Choice of market versus limit orders by informed and uninformed traders. Journal of Financial Markets, 8, 289-309.

Barclay, M. J., Hendershott, T., McCormick, D. T. (2003). Competition among trading venues: Information and trading on electronic communications networks. Journal of Finance, 58, 2637-2665.

Barclay, M. J., Warner, J. B. (1993). Stealth trading and volatility: Which trade move prices? Journal of Financial Economics, 34, 281-205.

Boehmer, E. (2005). Dimensions of execution quality: Recent evidence for US equity markets. Journal of Financial Economics, 78, 553 - 582.

Boehmer, E., Grammig, J., Theissen, E. (2007). Estimating the probability of informed trading - does trade misclassification matter? Journal of Financial Markets, 10, 26 - 47.

Brunnermeier, M. K., Pederssen, L. H. (2005). Predatory trading. Journal of Finance, $60,1825-1863$.

Chakravarty, S. (1994). Should actively traded futures contracts come under the dualtrading ban? Journal of Futures Markets, 6, 661-684.

Chakravarty, S. (2001). Stealth trading: Which traders' trades move stock prices? Journal of Financial Economics, 61, 289-307.

Chakravarty, S., Kalev, P. S., Pham, L. T. (2005). Stealth trading in volatile markets. Retrieved September 28, 2007, from Financial Management Association website: www.fma.org/Siena/Papers/350179.pdf

Chakravarty, S., Li, K. (2003a). A Bayesian analysis of dual trader informativeness in futures markets. Journal of Empirical Finance, 10, 355-371.

Chakravarty, S., Li, K. (2003b). An examination of own account trading by dual traders in futures markets. Journal of Financial Economics, 69, 375-397.

Chakravarty, S., Sarkar, A. (2002). A model of broker's trading with applications to order flow internalization. Review of Financial Economics, 11, 19-36. 
Charoenwong, C., Jenwittayaroje, N. (2007). Which trade sizes move stock prices in a fully automated order-driven market? A case of the stock exchange of Thailand. Retrieved October 15, 2007 from The China Center for Financial Research website: www.ccfr.org.cn/cicf2007/download.php?paper=20070115120603.PDF

Easley, D., Kiefer, N. M., O'Hara, M. (1996). Cream-skimming or profit-sharing? The curious role of purchased order flow. Journal of Finance, 51, 811-833.

Economides, N., Schwartz, R. (1995). Equity trading practices and market structure: Assessing asset managers' demand for immediacy. Working Paper, New York University Stern School of Business, No. EC-95-08.

Fishman, M.J., Longstaff, F. (1992). Dual trading in futures markets. Journal of Finance, 47, 643-671.

Garfinkel, J. A., Nimalendran, M. (2003). Market structure and trader anonymity: An analysis of insider trading. Journal of Financial and Quantitative Analysis, 38, 591 -610.

Grammig, J., Schiereck, D., Theissen, E. (2001). Knowing me, knowing you: Trader anonymity and informed trading in parallel markets. Journal of Financial Markets, 4, $385-412$.

Grossman, S. J. (1989). An economic analysis of dual trading. Rodney L. White Center for Financial Research Paper 33-89, The Wharton School, University of Pennsylvania.

Hanousek, J., Podpiera, R. (2002). Information-driven trading at the Prague Stock Exchange. Economics of Transition, 10(3), 747-759.

Hanousek, J., Podpiera, R. (2004). Czech experience with market maker trading system. Economic Systems, 28(1), 177-91.

Hasbrouck, J., Sofianos, G. (1993). The trades of market makers: An empirical analysis of NYSE specialists. Journal of Finance, 48, 1565 - 1593.

Heidl, H. G., Huang, R. D. (2002). Information-based trading in dealer and auction markets: An analysis of exchange listings. Journal of Financial and Quantitative Analysis, 37, $391-424$.

Huang, R. (2002). The quality of ECN and NASDAQ market-maker quotes. Journal of Finance, 57, $1285-1319$.

Huang, R. D., Stoll, H. R. (1996). Dealer versus auction markets: A paired comparison of execution costs on NASDAQ and the NYSE. Journal of Financial Economics, 41, $313-357$.

Kurov, A., Lasser, D. (2004). Price dynamics in the regular and E-mini futures markets. Journal of Financial and Quantitative Analysis, 39, 365-384. 
Kyle, A. (1985). Continuous auctions and insider trading. Econometrica, 47, 331-359.

Lee, Ch. M. C., Ready, M. J. (1991). Inferring trade direction from intraday data. Journal of Finance, 41, $733-746$.

Lee, J., Yi, C. H. (2001). Trade size and information-motivated trading in the options and stock markets. Journal of Financial and Quantitative Analysis, 36, 485 -501.

Madhavan, A., Panchapagesan, V. (2000). Price discovery in auction markets: A look insided the black box. Review of Financial Studies, 13, 627-658.

Roell, A. (1990). Dual capacity trading and the quality of the market. Journal of Financial Intermediation, 1, 105-124.

Saar, G. (2001). Investor uncertainty and order flow information. Working Paper, New York University Stern School of Business, No. FIN-01-063.

Sarkar, A. (1995). Dual trading: Winners, losers and market impact. Journal of Financial Intermediation, 4, 77-93.

Seppi, D. (1990). Equilibrium block trading and asymmetric information. Journal of Finance, 45, 73 - 94.

Smith, B., Turnbull, A., White, R. (2001). Upstairs market for principal and agency trades: Analysis of adverse information and price effects. Journal of Finance, 56, 1723 1746.

Vega, C. (2006). Stock price reaction to public and private information. Journal of Financial Economics, 82, 103 - 133.

Wang, A., Chae, J. (2003). Who makes markets? Cross-sectional variation in voluntary liquidity provision. MIT Sloan Working Paper No. 4434-03. 
Figure 1: Trading Tree diagram

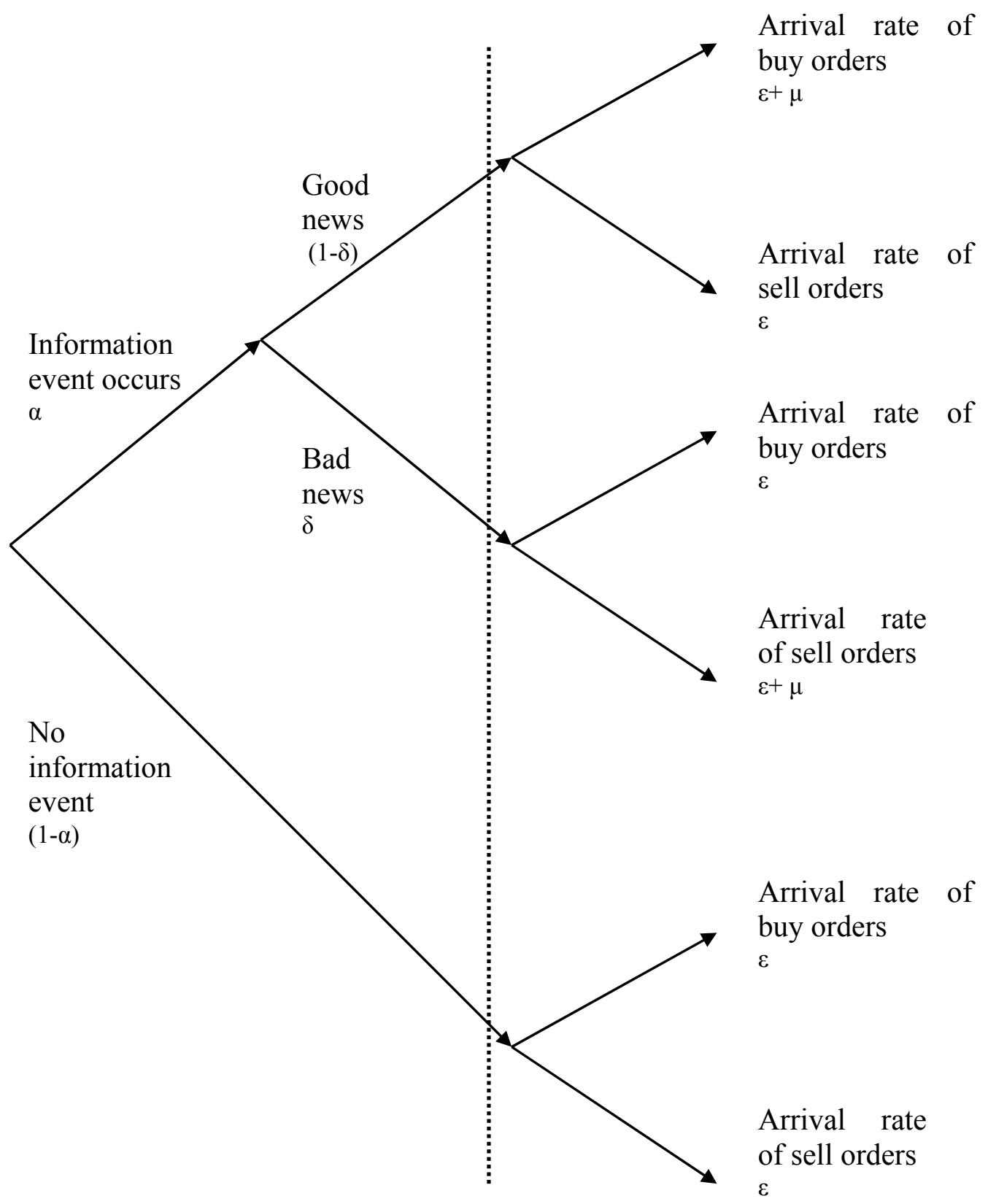

Before trading day

During trading day

The diagram depicts the structure of arriving buy and sell orders during a trading day, where $\alpha$ is the probability of an information event occurring, $\delta$ is the probability of bad news, $\mu$ is the arrival rate of informed traders, $\varepsilon$ is the arrival rate of uninformed traders. 
Table 1: Market capitalization and overall traded volumes

\begin{tabular}{|c|c|c|c|c|c|c|c|c|c|c|}
\hline stock & year & $\begin{array}{l}\text { Market } \\
\text { capital. }\end{array}$ & $\begin{array}{l}\text { Overall } \\
\text { traded } \\
\text { volume }\end{array}$ & $\begin{array}{c}\text { SPAD } \\
\text { pct }\end{array}$ & $\begin{array}{l}\text { Sys. } \\
\text { pct }\end{array}$ & APD & $B / S$ & price & $\begin{array}{c}\text { price } \\
\text { change }\end{array}$ & MM \\
\hline \multirow{2}{*}{ CME } & 2005 & 42948.8 & 5945.1 & 0.81 & 0.56 & 18.3 & 1.30 & 1409.0 & $18.0 \%$ & 6 \\
\hline & 2006 & 50178.6 & 25239.0 & 0.95 & $0.62^{*}$ & 41.4 & 1.03 & 1462.0 & $3.8 \%$ & 6 \\
\hline \multirow{4}{*}{ ČEZ } & 2003 & 86285.1 & 44242.4 & 0.64 & 0.31 & 18.4 & 1.14 & 145.7 & $57.6 \%$ & 10 \\
\hline & 2004 & 201766.2 & 108047.2 & 0.73 & 0.42 & 42.0 & 1.29 & 340.7 & $133.8 \%$ & 9 \\
\hline & 2005 & 436044.8 & 298733.9 & 0.68 & 0.45 & 124.5 & 1.04 & 736.3 & $116.1 \%$ & 10 \\
\hline & 2006 & 568522.4 & 347499.0 & 0.91 & $0.50^{*}$ & 161.8 & 0.90 & 960.0 & $30.4 \%$ & 9 \\
\hline \multirow{2}{*}{ CRA } & 2003 & 10660.5 & 4751.2 & 0.72 & 0.25 & 5.3 & 2.00 & 345.0 & $82.5 \%$ & 8 \\
\hline & 2004 & 13719.6 & 9216.3 & 0.61 & 0.29 & 9.8 & 1.12 & 444.0 & $28.7 \%$ & 8 \\
\hline \multirow{4}{*}{ EB } & 2003 & 190961.8 & 12969.3 & 0.78 & 0.61 & 17.4 & 1.18 & 798.0 & $59.0 \%$ & 6 \\
\hline & 2004 & 286592.7 & 31141.9 & 0.85 & 0.63 & 31.6 & 1.15 & 1187.0 & $48.8 \%$ & 6 \\
\hline & 2005 & 333647.9 & 47744.1 & 0.83 & 0.63 & 43.5 & 0.97 & 1372.0 & $15.6 \%$ & 8 \\
\hline & 2006 & 504789.2 & 58093.0 & 0.93 & $0.63^{*}$ & 48.4 & 0.99 & 1601.0 & $16.7 \%$ & 9 \\
\hline \multirow{4}{*}{ KB } & 2003 & 91907.8 & 101157.7 & 0.65 & 0.40 & 38.0 & 0.96 & 2418.0 & $16.4 \%$ & 9 \\
\hline & 2004 & 124368.2 & 149252.7 & 0.60 & 0.34 & 61.1 & 0.95 & 3272.0 & $35.3 \%$ & 9 \\
\hline & 2005 & 130791.9 & 206388.0 & 0.64 & 0.43 & 95.1 & 0.92 & 3441.0 & $5.2 \%$ & 10 \\
\hline & 2006 & 117792.5 & 105570.7 & 0.92 & $0.57^{*}$ & 70.2 & 0.93 & 3099.0 & $-9.9 \%$ & 8 \\
\hline \multirow{4}{*}{02} & 2003 & 93824.8 & 64924.1 & 0.49 & 0.17 & 22.5 & 1.19 & 291.3 & $19.0 \%$ & 10 \\
\hline & 2004 & 118915.6 & 121040.1 & 0.52 & 0.16 & 36.0 & 1.19 & 369.2 & $26.7 \%$ & 9 \\
\hline & 2005 & 168936.1 & 288306.4 & 0.44 & 0.14 & 43.0 & 1.04 & 524.5 & $42.1 \%$ & 10 \\
\hline & 2006 & 153314.8 & 98669.9 & 0.91 & $0.44^{*}$ & 56.6 & 0.80 & 476.0 & $-9.3 \%$ & 10 \\
\hline \multirow{2}{*}{ ORCO } & 2005 & & 5697.7 & 0.78 & 0.61 & 18.8 & 1.17 & 1809.0 & $40.7 \%$ & 6 \\
\hline & 2006 & 22478.2 & 28062.0 & 0.95 & $0.72^{*}$ & 62.1 & 1.08 & 2755.0 & $52.3 \%$ & 6 \\
\hline \multirow{4}{*}{ PM } & 2003 & 30098.6 & 19186.9 & 0.67 & 0.38 & 9.1 & 1.24 & 15728.0 & $41.1 \%$ & 9 \\
\hline & 2004 & 32104.2 & 29238.1 & 0.72 & 0.41 & 22.2 & 0.98 & 16776.0 & $6.7 \%$ & 8 \\
\hline & 2005 & 34926.9 & 35305.0 & 0.68 & 0.43 & 28.2 & 1.16 & 18251.0 & $8.8 \%$ & 8 \\
\hline & 2006 & 20744.5 & 18449.6 & 0.90 & $0.49^{*}$ & 24.9 & 0.86 & 10840.0 & $-40.6 \%$ & 7 \\
\hline \multirow{4}{*}{ UNI } & 2003 & 12047.9 & 8659.8 & 0.60 & 0.34 & 8.2 & 1.26 & 66.4 & $92.1 \%$ & 8 \\
\hline & 2004 & 17807.1 & 14064.3 & 0.68 & 0.35 & 9.5 & 0.96 & 98.2 & $47.8 \%$ & 8 \\
\hline & 2005 & 42160.3 & 51243.6 & 0.78 & 0.54 & 45.1 & 1.03 & 232.5 & $136.8 \%$ & 8 \\
\hline & 2006 & 42486.7 & 48461.9 & 0.90 & $0.59^{*}$ & 46.1 & 0.93 & 234.3 & $0.8 \%$ & 6 \\
\hline \multirow{3}{*}{ ZEN } & 2004 & 28892.0 & 17023.4 & 0.65 & 0.30 & 17.0 & 1.09 & 757.6 & $50.0 \%$ & 8 \\
\hline & 2005 & 43322.8 & 100548.7 & 0.61 & 0.38 & 48.5 & 1.02 & 1136.0 & $50.0 \%$ & 8 \\
\hline & 2006 & 48356.7 & 107218.1 & 0.92 & $0.60^{*}$ & 75.5 & 1.03 & 1268.0 & $11.6 \%$ & 9 \\
\hline
\end{tabular}

Market capital. - market capitalization in million of CZK; Overall traded volume - overall traded volume in million of CZK; SPAD pct - ratio of the SPAD traded volume on overall traded volume; Sys. pct - ratio of system trades (usually classic trades with the identification of market maker) on the overall traded volume; APD - average number of trades during a trading day; $\mathrm{B} / \mathrm{S}$ - buy over sells ratio; price - price at the beginning of the year; price change - percentage change of price during the last year; $\mathrm{MM}$ - number of market makers following the stock during the given year;

* computed using information about trades just from the first half of the year 2006.

Source: www.pse.cz, www.akcie.cz and author's computations. 
Table 2: Market share of market makers on the PSE during the sample period

\begin{tabular}{|c|c|c|c|c|c|c|c|c|c|c|}
\hline Stock & CME & ČEZ & CRA & EB & KB & 02 & ORCO & PM & UNI & ZEN \\
\hline \multirow{2}{*}{ IM 1} & $20.57 \%$ & $15.04 \%$ & $11.56 \%$ & $17.42 \%$ & $16.33 \%$ & $13.06 \%$ & $19.83 \%$ & $15.35 \%$ & $20.64 \%$ & $15.95 \%$ \\
\hline & 1870 & 9648 & 297 & 4629 & 8327 & 4455 & 2617 & 2505 & 4190 & 3718 \\
\hline \multirow{2}{*}{ MM 2} & $14.92 \%$ & $9.44 \%$ & $7.74 \%$ & $6.49 \%$ & $1.12 \%$ & $5.75 \%$ & & $10.62 \%$ & $9.21 \%$ & $10.77 \%$ \\
\hline & 1356 & 6059 & 199 & 1725 & 571 & 1961 & 0 & 1732 & 1870 & 2511 \\
\hline \multirow{2}{*}{ MM 3} & & $0.26 \%$ & $1.79 \%$ & & $0.63 \%$ & $0.89 \%$ & & $0.48 \%$ & $0.48 \%$ & \\
\hline & 0 & 165 & 46 & 0 & 320 & 305 & 0 & 79 & 97 & 0 \\
\hline \multirow{2}{*}{ MM 4} & $15.87 \%$ & $11.63 \%$ & $13.81 \%$ & $14.38 \%$ & $12.64 \%$ & $11.93 \%$ & $15.21 \%$ & $13.16 \%$ & $15.22 \%$ & $12.54 \%$ \\
\hline & 1443 & 7461 & 355 & 3820 & 6449 & 4070 & 2007 & 2147 & 3089 & 2922 \\
\hline \multirow{2}{*}{ MM 5} & $15.35 \%$ & $10.09 \%$ & $13.54 \%$ & $12.47 \%$ & $11.97 \%$ & $9.01 \%$ & $15.98 \%$ & $13.75 \%$ & $17.69 \%$ & $8.92 \%$ \\
\hline & 1395 & 6476 & 348 & 3313 & 6103 & 3075 & 2108 & 2244 & 3591 & 2079 \\
\hline \multirow{2}{*}{ MM 6} & & $9.31 \%$ & $6.58 \%$ & $4.81 \%$ & $9.62 \%$ & $7.82 \%$ & & $10.50 \%$ & $1.56 \%$ & $9.96 \%$ \\
\hline & 0 & 5973 & 169 & 1277 & 4906 & 2669 & 0 & 1713 & 317 & 2322 \\
\hline \multirow{2}{*}{ MM 7} & $17.73 \%$ & $14.95 \%$ & $16.46 \%$ & $14.02 \%$ & $14.37 \%$ & $25.56 \%$ & $16.51 \%$ & $15.61 \%$ & $17.72 \%$ & $14.67 \%$ \\
\hline & 1612 & 9589 & 423 & 3725 & 7327 & 8721 & 2178 & 2547 & 3597 & 3419 \\
\hline \multirow{2}{*}{ MM 8} & & $1.10 \%$ & & & $1.33 \%$ & $1.82 \%$ & & & & \\
\hline & 0 & 703 & 0 & 0 & 680 & 622 & 0 & $\overline{0}$ & 0 & 0 \\
\hline \multirow{2}{*}{ MM 9} & & $8.79 \%$ & $10.04 \%$ & $12.44 \%$ & $10.74 \%$ & $6.81 \%$ & $15.04 \%$ & $5.94 \%$ & $3.97 \%$ & $10.77 \%$ \\
\hline & 0 & 5639 & 258 & 3305 & 5478 & 2323 & 1985 & 969 & 806 & 2511 \\
\hline \multirow{2}{*}{ MM 10} & & $6.49 \%$ & & $1.14 \%$ & $7.43 \%$ & $3.01 \%$ & & & & $2.73 \%$ \\
\hline & 0 & 4167 & 0 & 302 & 3791 & 1026 & 0 & 0 & 0 & 636 \\
\hline MM 11 & $\begin{array}{r}\mathbf{1 5 . 5 6 \%} \\
1414\end{array}$ & $\begin{array}{r}12.90 \% \\
8276\end{array}$ & $\begin{array}{r}\mathbf{1 8 . 4 8 \%} \\
475\end{array}$ & $\begin{array}{r}16.82 \% \\
4469\end{array}$ & $\begin{array}{r}\mathbf{1 3 . 8 2 \%} \\
7050\end{array}$ & $\begin{array}{r}14.30 \% \\
4880\end{array}$ & $\begin{array}{r}\mathbf{1 7 . 4 2 \%} \\
2299\end{array}$ & $\begin{array}{r}14.58 \% \\
2379\end{array}$ & $\begin{array}{r}\mathbf{1 3 . 5 0 \%} \\
2739\end{array}$ & $\begin{array}{r}13.68 \% \\
3189\end{array}$ \\
\hline
\end{tabular}

Each row consists of percentage and number of trades of a given market maker during the sample period 1.1.2003 through 30.9.2006.

Source: www.akcie.cz and author's computations 
Table 3: SPAD traded volume and percentage of block trades

\begin{tabular}{c|c|r|r|r|r|r}
\hline Stock & year & \multicolumn{1}{c|}{ volume } & block trades & SPAD with ID & SPAD no ID & $\begin{array}{c}\text { SPAD ID } \\
\text { no cross }\end{array}$ \\
\hline CME & 2005 & 5.920 bil CZK & $\mathbf{1 6 . 6 6 \%}$ & $55.20 \%$ & $25.70 \%$ & $\mathbf{5 2 . 1 6 \%}$ \\
CME & 2006 & 19.261 bil CZK & $\mathbf{3 . 7 3 \%}$ & $63.50 \%$ & $27.93 \%$ & $\mathbf{5 9 . 7 5 \%}$ \\
\hline CRA & $03-04$ & 14.221 bil CZK & $\mathbf{3 1 . 9 1 \%}$ & $24.85 \%$ & $40.78 \%$ & $\mathbf{2 3 . 4 6 \%}$ \\
\hline ČEZ & $03-05$ & 445.639 bil CZK & $\mathbf{2 9 . 5 8 \%}$ & $41.81 \%$ & $27.46 \%$ & $\mathbf{3 9 . 5 3 \%}$ \\
ČEZ & 2006 & 261.958 bil CZK & $\mathbf{6 . 5 9} \%$ & $48.51 \%$ & $39.47 \%$ & $\mathbf{4 6 . 0 5 \%}$ \\
\hline EB & $03-05$ & 91.382 bil CZK & $\mathbf{1 5 . 7 4 \%}$ & $62.20 \%$ & $20.44 \%$ & $\mathbf{5 8 . 5 7 \%}$ \\
EB & 2006 & 38.989 bil CZK & $\mathbf{5 . 5 6 \%}$ & $65.03 \%$ & $27.54 \%$ & $\mathbf{6 2 . 4 0 \%}$ \\
\hline KB & $03-05$ & 448.635 bil CZK & $\mathbf{3 6 . 5 7 \%}$ & $38.51 \%$ & $23.85 \%$ & $\mathbf{3 6 . 2 1 \%}$ \\
KB & 2006 & 80.878 bil CZK & $\mathbf{7 . 0 6 \%}$ & $58.02 \%$ & $29.82 \%$ & $\mathbf{5 5 . 0 7 \%}$ \\
\hline ORCO & 2005 & 5.552 bil CZK & $\mathbf{1 9 . 5 8 \%}$ & $60.16 \%$ & $19.37 \%$ & $\mathbf{5 6 . 3 7 \%}$ \\
ORCO & 2006 & 20.925 bil CZK & $\mathbf{5 . 4 2 \%}$ & $75.01 \%$ & $17.53 \%$ & $\mathbf{6 9 . 9 6 \%}$ \\
\hline PM & $03-05$ & 82.659 bil CZK & $\mathbf{2 9 . 8 0 \%}$ & $39.03 \%$ & $29.78 \%$ & $\mathbf{3 6 . 2 9 \%}$ \\
PM & 2006 & 15.667 bil CZK & $\mathbf{7 . 7 3 \%}$ & $45.96 \%$ & $40.60 \%$ & $\mathbf{4 2 . 8 6 \%}$ \\
\hline O2 & $03-05$ & 472.372 bil CZK & $\mathbf{5 3 . 2 5 \%}$ & $13.76 \%$ & $31.79 \%$ & $\mathbf{1 2 . 9 7 \%}$ \\
O2 & 2006 & 75.774 bil CZK & $\mathbf{1 5 . 1 7 \%}$ & $40.00 \%$ & $40.32 \%$ & $\mathbf{3 7 . 1 9 \%}$ \\
\hline UNI & $03-05$ & 70.906 bil CZK & $\mathbf{2 2 . 4 3 \%}$ & $44.73 \%$ & $31.26 \%$ & $\mathbf{4 1 . 4 6 \%}$ \\
UNI & 2006 & 38.485 bil CZK & $\mathbf{5 . 6 5 \%}$ & $57.77 \%$ & $34.17 \%$ & $\mathbf{5 2 . 0 4 \%}$ \\
\hline ZEN & $04-05$ & 119.943 bil CZK & $\mathbf{3 8 . 8 9 \%}$ & $35.41 \%$ & $24.79 \%$ & $\mathbf{3 3 . 4 6 \%}$ \\
ZEN & 2006 & 84.371 bil CZK & $\mathbf{5 . 6 3 \%}$ & $60.94 \%$ & $30.17 \%$ & $\mathbf{5 8 . 0 1 \%}$ \\
\hline VO
\end{tabular}

Volume - traded volume on SPAD; block trades - percentage of SPAD volume; SPAD with ID (no ID) percentage of SPAD traded volume with (without) identification of the market maker; SPAD ID no cross percentage of SPAD traded volume analyzed in our study (standard SPAD trades through the market maker).

Source: www.pse.cz, www.akcie.cz and author's computations 
Table 4: Changes in trading lot size

\begin{tabular}{|c|c|c|c|c|c|c|}
\hline Stock & Time period & LOT & $\begin{array}{c}\text { Price } \\
\text { first }\end{array}$ & $\begin{array}{c}\text { Price } \\
\text { last }\end{array}$ & $\begin{array}{c}\text { Volume } \\
\text { first }\end{array}$ & Volume last \\
\hline CME & 27.6.2005-29.9.2006 & 1000 & 1194 & 1516 & $1.194 \mathrm{mil}$ & $1.516 \mathrm{mil} \mathrm{CZK}$ \\
\hline CRA & $2.1 .2003-22.4 .2004$ & 3000 & 187.5 & 450 & $0.563 \mathrm{mil}$ & $1.350 \mathrm{mil} \mathrm{CZK}$ \\
\hline ČEZ & $2.1 .2003-15.10 .2004$ & 20000 & 92.37 & 265.3 & $1.847 \mathrm{mil}$ & $5.306 \mathrm{mil} \mathrm{CZK}$ \\
\hline ČEZ & $18.10 .2004-12.8 .2005$ & 10000 & 258.7 & 549.3 & $2.587 \mathrm{mil}$ & $5.493 \mathrm{mil} \mathrm{CZK}$ \\
\hline ČEZ & 15.8.2005-29.9.2006 & 5000 & 553.5 & 790.5 & $2.768 \mathrm{mil}$ & $3.953 \mathrm{mil} \mathrm{CZK}$ \\
\hline EB & $2.1 .2003-19.9 .2003$ & 500 & 2022 & 2805 & $1.011 \mathrm{mil}$ & $1.403 \mathrm{mil} \mathrm{CZK}$ \\
\hline EB & 22.9.2003-12.3.2004 & 1000 & 2757 & 3793 & $2.757 \mathrm{mil}$ & $3.793 \mathrm{mil} \mathrm{CZK}$ \\
\hline EB & 15.3.2004-7.7.2004 & 500 & 3761 & 4189 & $1.881 \mathrm{mil}$ & $2.095 \mathrm{mil} \mathrm{CZK}$ \\
\hline EB & $8.7 .2004-30.9 .2006$ & 2000 & 1041 & 1405 & $2.082 \mathrm{mil}$ & $2.810 \mathrm{mil} \mathrm{CZK}$ \\
\hline$\overline{K B}$ & $2.1 .2003-19.9 .2003$ & 2000 & 2118 & 2485 & $4.236 \mathrm{mil}$ & $4.970 \mathrm{mil} \mathrm{CZK}$ \\
\hline KB & 22.9.2003-30.9.2006 & 1000 & 2447 & 3308 & $2.447 \mathrm{mil}$ & $3.308 \mathrm{mil} \mathrm{CZK}$ \\
\hline ORCO & $1.2 .2005-30.9 .2006$ & 500 & 1286 & 2802 & $0.643 \mathrm{mil}$ & $1.401 \mathrm{mil} \mathrm{CZK}$ \\
\hline PM & $2.1 .2003-12.3 .2004$ & 200 & 11432 & 19860 & $2.286 \mathrm{mil}$ & $3.972 \mathrm{mil} \mathrm{CZK}$ \\
\hline PM & 15.3.2004-30.9.2006 & 100 & 19470 & 9828 & $1.947 \mathrm{mil}$ & $0.983 \mathrm{mil} \mathrm{CZK}$ \\
\hline 02 & $2.1 .2003-30.9 .2006$ & 5000 & 247.7 & 441.8 & $1.239 \mathrm{mil}$ & $2.209 \mathrm{mil} \mathrm{CZK}$ \\
\hline UNI & $2.1 .2003-24.2 .2005$ & 20000 & 34.96 & 169.35 & $0.699 \mathrm{mil}$ & $3.387 \mathrm{mil} \mathrm{CZK}$ \\
\hline UNI & 25.2.2005-30.9.2006 & 10000 & 170.4 & 196.59 & $1.704 \mathrm{mil}$ & $1.966 \mathrm{mil} \mathrm{CZK}$ \\
\hline ZEN & 28.6.2004-30.9.2006 & 3000 & 504.5 & 1301 & $1.514 \mathrm{mil}$ & 3.903 mil CZK \\
\hline
\end{tabular}

LOT - number of shares of trading lot; Price and Volume first - price and volume at the beginning of the corresponding time period, Price and Volume last - price and volume at the end of the time period in CZK

Source: www.pse.cz, www.akcie.cz and author's computations 
Table 5: Extent of information-driven trading originating from the behavior of informed market makers

\begin{tabular}{|c|c|c|c|c|c|c|c|c|}
\hline Stock & Time period & $\begin{array}{l}\mathrm{am} / \\
\mathrm{pm}\end{array}$ & PIN & PIN MM & MM & Diff & T-stat & P-value \\
\hline CRA & $\begin{array}{l}26.6 .2003- \\
15.10 .2003 \\
\end{array}$ & $\mathrm{pm}$ & $\begin{array}{l}\mathbf{0 . 5 3 1} \\
(0.101) \\
\end{array}$ & $\begin{array}{l}\mathbf{0 . 8 0 8} \\
(0.084) \\
\end{array}$ & MM 4 & $\begin{array}{l}\mathbf{0 . 2 7 7} \\
(0.138) \\
\end{array}$ & 2.01 & 0.045 \\
\hline ČEZ & $\begin{array}{l}2.1 .2003- \\
2.8 .2004 \\
\end{array}$ & $\mathrm{pm}$ & $\begin{array}{l}\mathbf{0 . 5 0 4} \\
(0.020) \\
\end{array}$ & $\begin{array}{l}\mathbf{0 . 5 5 5} \\
(0.020) \\
\end{array}$ & MM 7 & $\begin{array}{l}\mathbf{0 . 0 5 1} \\
(0.029) \\
\end{array}$ & 1.79 & 0.074 \\
\hline EB & $\begin{array}{c}25.5 .2004- \\
1.11 .2004\end{array}$ & am & $\begin{array}{l}\mathbf{0 . 3 2 8} \\
(0.036)\end{array}$ & $\begin{array}{l}\mathbf{0 . 2 2 7} \\
(0.039)\end{array}$ & MM 1 & $\begin{array}{l}-\mathbf{0 . 1 0 2} \\
(0.053)\end{array}$ & 1.92 & 0.055 \\
\hline KB & $\begin{array}{c}5.2 .2003- \\
7.7 .2003 \\
\end{array}$ & $\mathrm{pm}$ & $\begin{array}{l}\mathbf{0 . 5 4 0} \\
(0.034) \\
\end{array}$ & $\begin{array}{r}\mathbf{0 . 6 1 3} \\
(0.031) \\
\end{array}$ & MM 7 & $\begin{array}{l}\mathbf{0 . 0 7 4} \\
(0.046) \\
\end{array}$ & 1.61 & 0.108 \\
\hline KB & $\begin{array}{l}2.9 .2005- \\
26.1 .2006 \\
\end{array}$ & $\mathrm{pm}$ & $\begin{array}{l}\mathbf{0 . 3 6 8} \\
(0.040) \\
\end{array}$ & $\begin{array}{l}\mathbf{0 . 4 6 6} \\
(0.038) \\
\end{array}$ & MM 7 & $\begin{array}{l}\mathbf{0 . 0 9 9} \\
(0.055) \\
\end{array}$ & 1.80 & 0.071 \\
\hline PM & $\begin{array}{l}14.6 .2004- \\
31.3 .2005 \\
\end{array}$ & $\mathrm{pm}$ & $\begin{array}{l}\mathbf{0 . 4 7 0} \\
(0.037) \\
\end{array}$ & $\begin{array}{l}\mathbf{0 . 5 8 0} \\
(0.033) \\
\end{array}$ & MM 7 & $\begin{array}{l}\mathbf{0 . 1 1 0} \\
(0.049) \\
\end{array}$ & 2.23 & 0.026 \\
\hline PM & $\begin{array}{l}21.7 .2004- \\
29.11 .2004 \\
\end{array}$ & $\mathrm{pm}$ & $\begin{array}{l}\mathbf{0 . 4 8 0} \\
(0.053) \\
\end{array}$ & $\begin{array}{l}\mathbf{0 . 5 8 4} \\
(0.044) \\
\end{array}$ & MM 7 & $\begin{array}{l}\mathbf{0 . 1 0 4} \\
(0.069) \\
\end{array}$ & 1.52 & 0.129 \\
\hline 02 & $\begin{array}{l}21.5 .2004- \\
31.8 .2004 \\
\end{array}$ & am & $\begin{array}{l}\mathbf{0 . 4 9 7} \\
(0.052) \\
\end{array}$ & $\begin{array}{l}\mathbf{0 . 6 4 8} \\
(0.045) \\
\end{array}$ & MM 7 & $\begin{array}{l}\mathbf{0 . 1 5 1} \\
(0.068)\end{array}$ & 2.21 & 0.027 \\
\hline 02 & $\begin{array}{c}11.6 .2004- \\
19.8 .2005 \\
\end{array}$ & $\mathrm{pm}$ & $\begin{array}{l}\mathbf{0 . 4 5 2} \\
(0.025) \\
\end{array}$ & $\begin{array}{l}\mathbf{0 . 5 3 8} \\
(0.023) \\
\end{array}$ & MM 7 & $\begin{array}{l}\mathbf{0 . 0 8 5} \\
(0.034) \\
\end{array}$ & 2.47 & 0.013 \\
\hline 02 & $\begin{array}{l}11.6 .2004- \\
27.12 .2004\end{array}$ & $\mathrm{pm}$ & $\begin{array}{l}\mathbf{0 . 4 7 4} \\
(0.034) \\
\end{array}$ & $\begin{array}{l}\mathbf{0 . 5 7 3} \\
(0.032) \\
\end{array}$ & MM 7 & $\begin{array}{l}\mathbf{0 . 0 9 8} \\
(0.047) \\
\end{array}$ & 2.09 & 0.036 \\
\hline 02 & $\begin{array}{c}20.4 .2005- \\
9.9 .2005 \\
\end{array}$ & am & $\begin{array}{l}\mathbf{0 . 5 4 6} \\
(0.045) \\
\end{array}$ & $\begin{array}{l}\mathbf{0 . 6 4 8} \\
(0.039) \\
\end{array}$ & MM 7 & $\begin{array}{l}\mathbf{0 . 1 0 1} \\
(0.059) \\
\end{array}$ & 1.71 & 0.088 \\
\hline 02 & $\begin{array}{c}8.11 .2005- \\
16.3 .2006 \\
\end{array}$ & am & $\begin{array}{l}\mathbf{0 . 3 4 9} \\
(0.048) \\
\end{array}$ & $\begin{array}{l}\mathbf{0 . 4 4 3} \\
(0.045) \\
\end{array}$ & MM 7 & $\begin{array}{l}\mathbf{0 . 0 9 4} \\
(0.065) \\
\end{array}$ & 1.44 & 0.151 \\
\hline 02 & $\begin{array}{c}21.12 .2005- \\
16.5 .2006 \\
\end{array}$ & $\mathrm{pm}$ & $\begin{array}{l}\mathbf{0 . 3 9 1} \\
(0.038) \\
\end{array}$ & $\begin{array}{l}\mathbf{0 . 4 7 4} \\
(0.036) \\
\end{array}$ & MM 7 & $\begin{array}{l}\mathbf{0 . 0 8 2} \\
(0.053) \\
\end{array}$ & 1.57 & 0.117 \\
\hline
\end{tabular}

The PIN MM is the estimate of information-driven trading using the sum of buys and sells except the buys and sells of a given market maker. Standard deviations are in parentheses below each estimation.

Source: www.akcie.cz and author's computations 
Table 6: Extent of information-driven trading before and after changing the lot size

\begin{tabular}{|c|c|c|c|c|c|c|c|c|c|}
\hline Stock & Date & LOT 1 & LOT 2 & $\begin{array}{l}\mathrm{am} / \\
\mathrm{pm}\end{array}$ & PIN 1 & PIN 2 & Diff & $\begin{array}{c}\mathrm{T}- \\
\text { stat }\end{array}$ & $\begin{array}{c}\text { P- } \\
\text { value }\end{array}$ \\
\hline ČEZ & 15.10.2004 & 20000 & 10000 & am & $\begin{array}{l}\mathbf{0 . 4 5 7} \\
(0.040)\end{array}$ & $\begin{array}{l}\mathbf{0 . 3 3 3} \\
(0.034)\end{array}$ & $\begin{array}{l}-0.123 \\
(0.053)\end{array}$ & 2.35 & 0.019 \\
\hline ČEZ & 15.10 .2004 & 20000 & 10000 & pm & $\begin{array}{l}\mathbf{0 . 5 1 4} \\
(0.044)\end{array}$ & $\begin{array}{l}\mathbf{0 . 3 7 2} \\
(0.037)\end{array}$ & $\begin{array}{l}-0.141 \\
(0.057)\end{array}$ & 2.46 & 0.014 \\
\hline ČEZ & 12.8 .2005 & 10000 & 5000 & am & $\begin{array}{l}\mathbf{0 . 2 8 6} \\
(0.034) \\
\end{array}$ & $\begin{array}{l}\mathbf{0 . 2 4 7} \\
(0.036) \\
\end{array}$ & $\begin{array}{l}-0.039 \\
(0.049)\end{array}$ & 0.78 & 0.434 \\
\hline ČEZ & 12.8 .2005 & 10000 & 5000 & pm & $\begin{array}{l}\mathbf{0 . 4 1 1} \\
(0.039) \\
\end{array}$ & $\begin{array}{l}\mathbf{0 . 3 3 4} \\
(0.038) \\
\end{array}$ & $\begin{array}{l}-0.077 \\
(0.055) \\
\end{array}$ & 1.41 & 0.160 \\
\hline KB & 5.9 .2003 & 2000 & 1000 & am & $\begin{array}{l}\mathbf{0 . 4 5 7} \\
(0.032)\end{array}$ & $\begin{array}{l}\mathbf{0 . 2 9 5} \\
(0.036)\end{array}$ & $\begin{array}{l}-0.161 \\
(0.048)\end{array}$ & 3.36 & 0.001 \\
\hline KB & 5.9 .2003 & 2000 & 1000 & pm & $\begin{array}{l}\mathbf{0 . 5 8 4} \\
(0.034)\end{array}$ & $\begin{array}{l}\mathbf{0 . 4 6 5} \\
(0.031)\end{array}$ & $\begin{array}{l}-0.119 \\
(0.046)\end{array}$ & 2.59 & 0.010 \\
\hline PM & 12.3.2004 & 200 & 100 & am & $\begin{array}{l}\mathbf{0 . 7 6 9} \\
(0.033)\end{array}$ & $\begin{array}{l}\mathbf{0 . 5 2 5} \\
(0.040)\end{array}$ & $\begin{array}{c}-0.244 \\
(0.051)\end{array}$ & 4.74 & 0.000 \\
\hline PM & 12.3.2004 & 200 & 100 & pm & $\begin{array}{l}\mathbf{0 . 7 3 2} \\
(0.041)\end{array}$ & $\begin{array}{l}\mathbf{0 . 4 8 8} \\
(0.058)\end{array}$ & $\begin{array}{c}-0.245 \\
(0.071)\end{array}$ & 3.43 & 0.001 \\
\hline UNI & 15.2 .2005 & 20000 & 10000 & am & $\begin{array}{l}\mathbf{0 . 4 8 1} \\
(0.079)\end{array}$ & $\begin{array}{l}\mathbf{0 . 2 5 9} \\
(0.051)\end{array}$ & $\begin{array}{c}-0.222 \\
(0.094)\end{array}$ & 2.36 & 0.018 \\
\hline UNI & 15.2 .2005 & 20000 & 10000 & $\mathrm{pm}$ & $\begin{array}{l}\mathbf{0 . 3 9 3} \\
(0.073)\end{array}$ & $\begin{array}{l}\mathbf{0 . 3 9 2} \\
(0.049)\end{array}$ & $\begin{array}{l}-0.001 \\
(0.086)\end{array}$ & 0.01 & 0.993 \\
\hline
\end{tabular}

Extent of information-driven trading within the 90 days of trading days before and after the change in lot size. Standard deviations are in parentheses below each estimation.

Source: www.akcie.cz and author's computations 
Figure 2a:

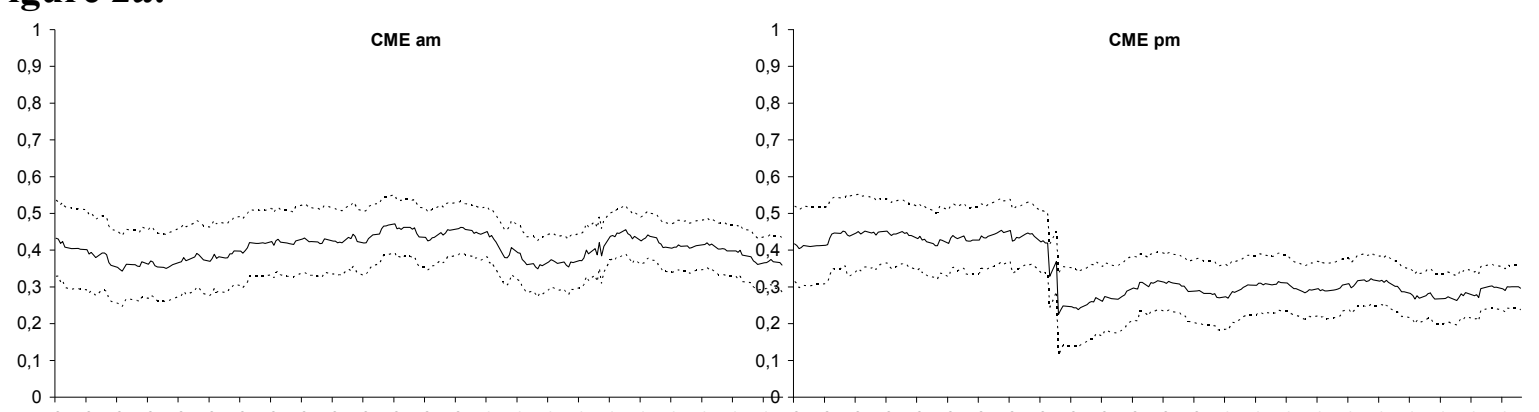

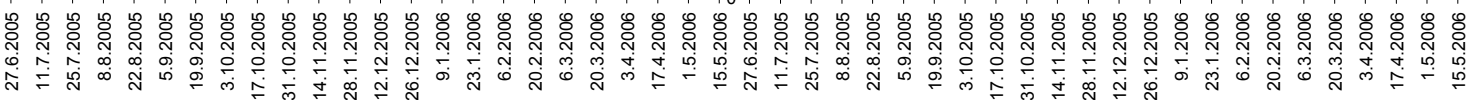
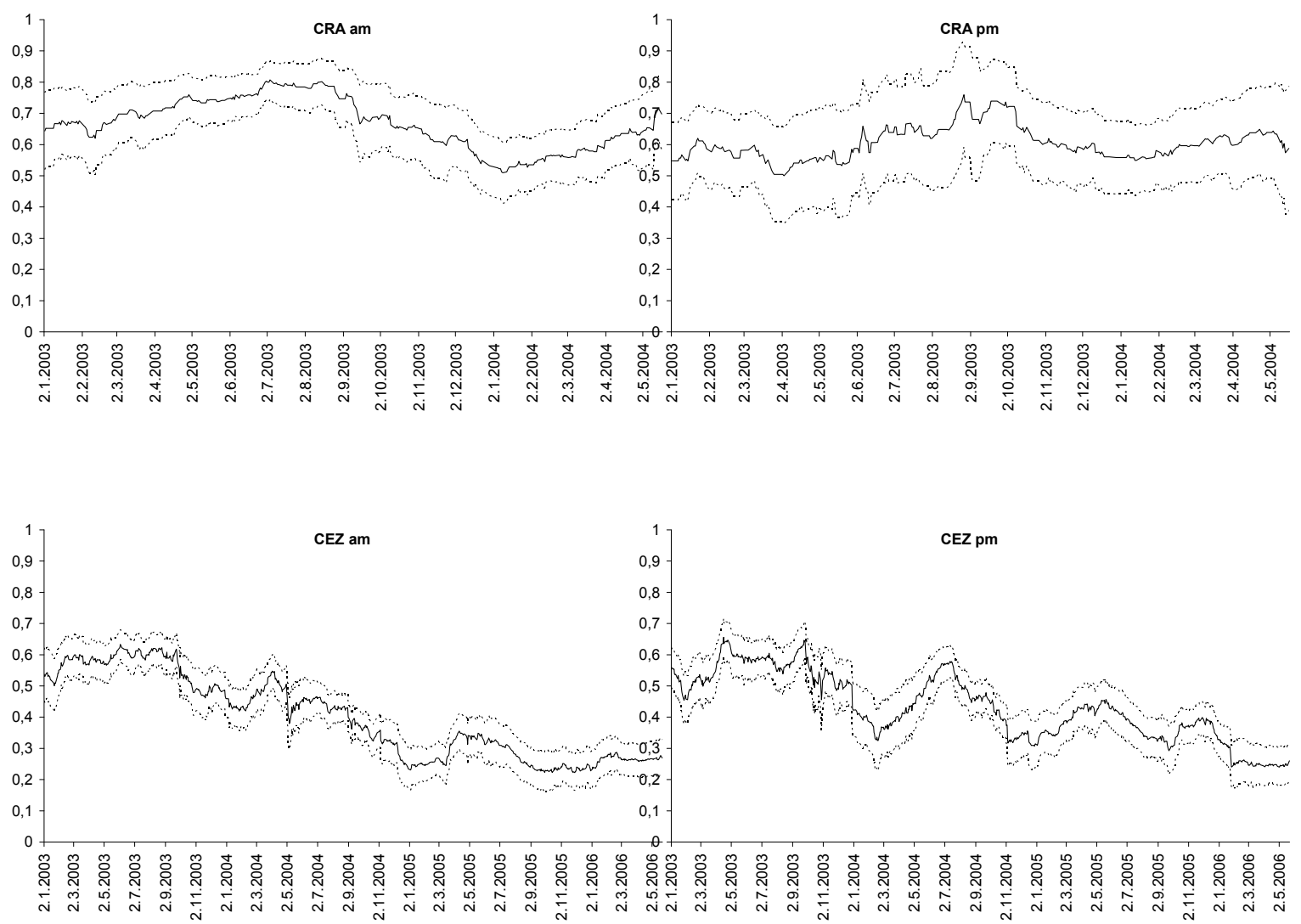

$\mathrm{y}$-axis - PIN, $\mathrm{x}$-axis - initial date of 90 day estimation period

Source: www.akcie.cz and author's computations 


\section{Figure 2b:}
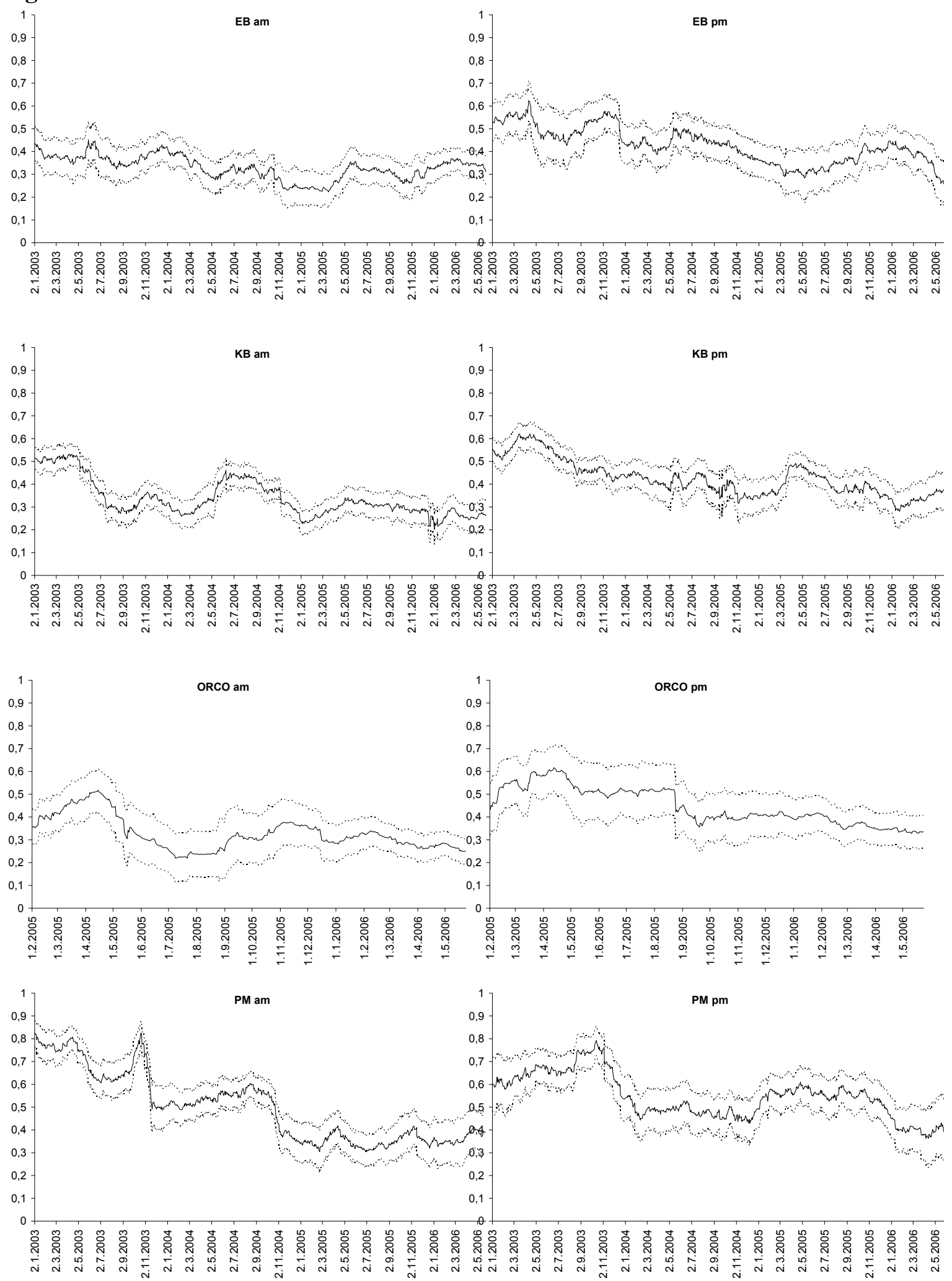

$y$-axis - PIN, x-axis - initial date of 90 day estimation period

Source: www.akcie.cz and author's computations 


\section{Figure 2c:}
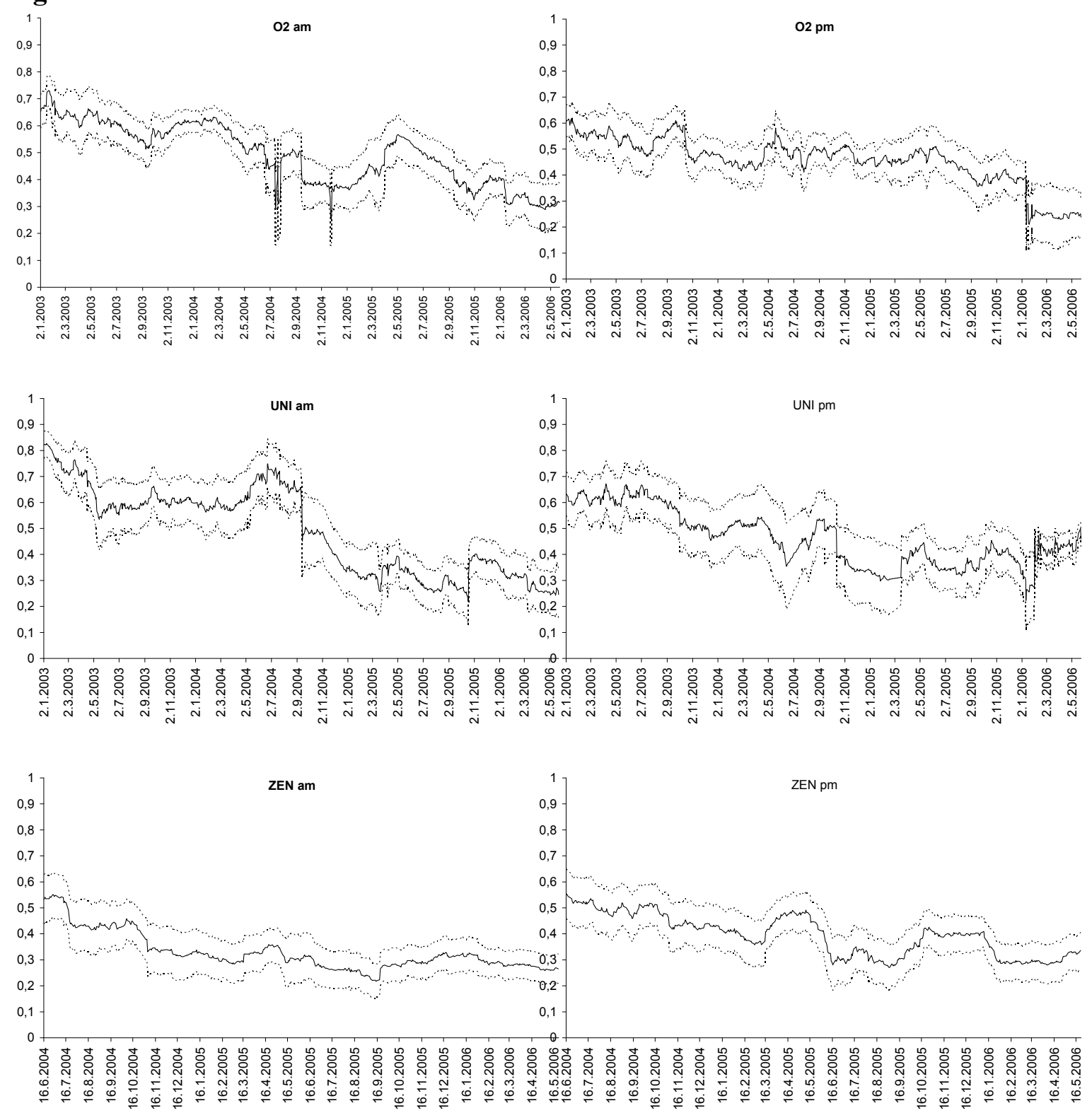

$\mathrm{y}$-axis - PIN, $\mathrm{x}$-axis - initial date of 90 day estimation period

Source: www.akcie.cz and author's computations 
Figure 3

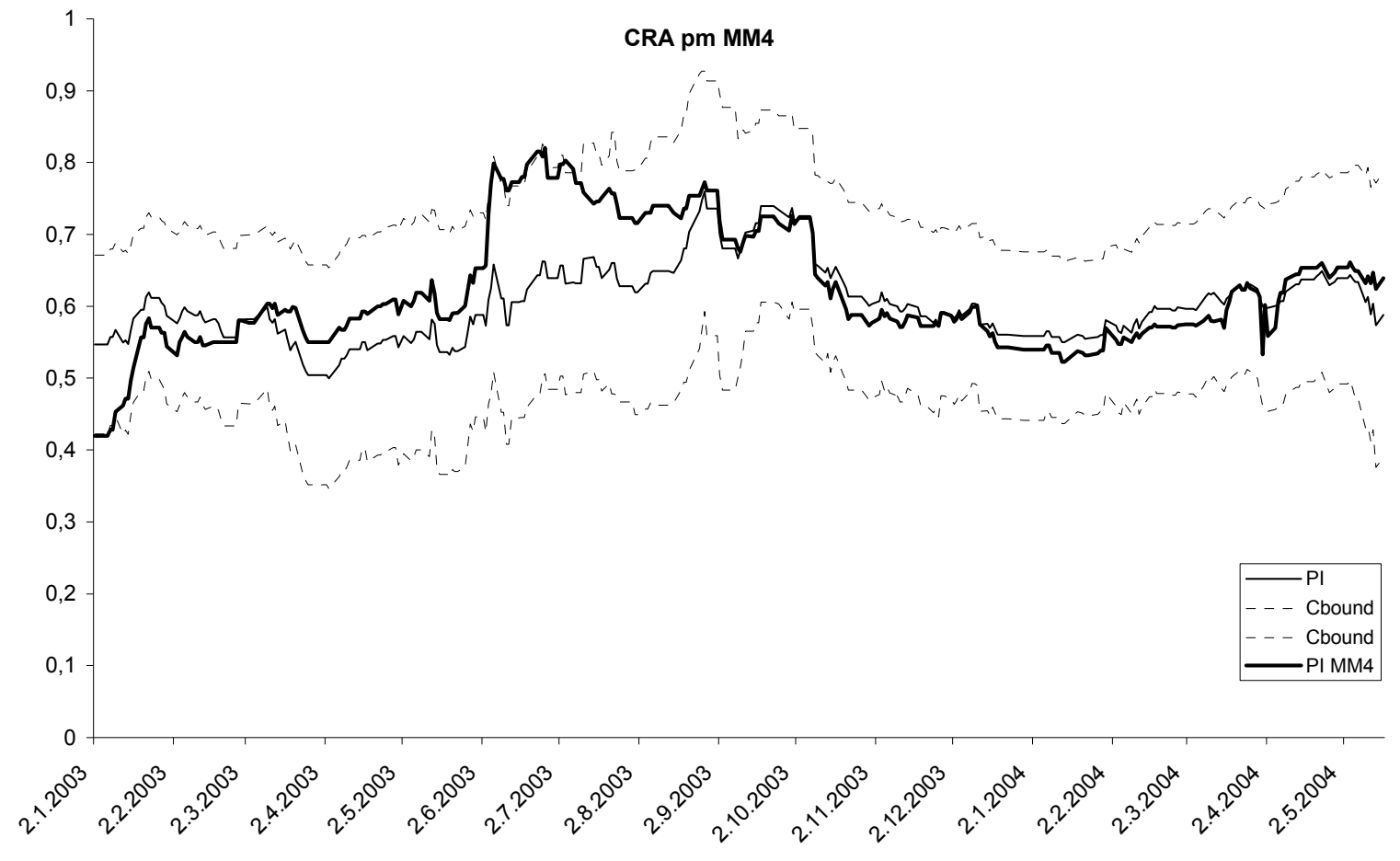

$\mathrm{y}$-axis - PIN, $\mathrm{x}$-axis - initial date of 90 day estimation period

Source: www.akcie.cz and author's computations

\section{Figure 4}

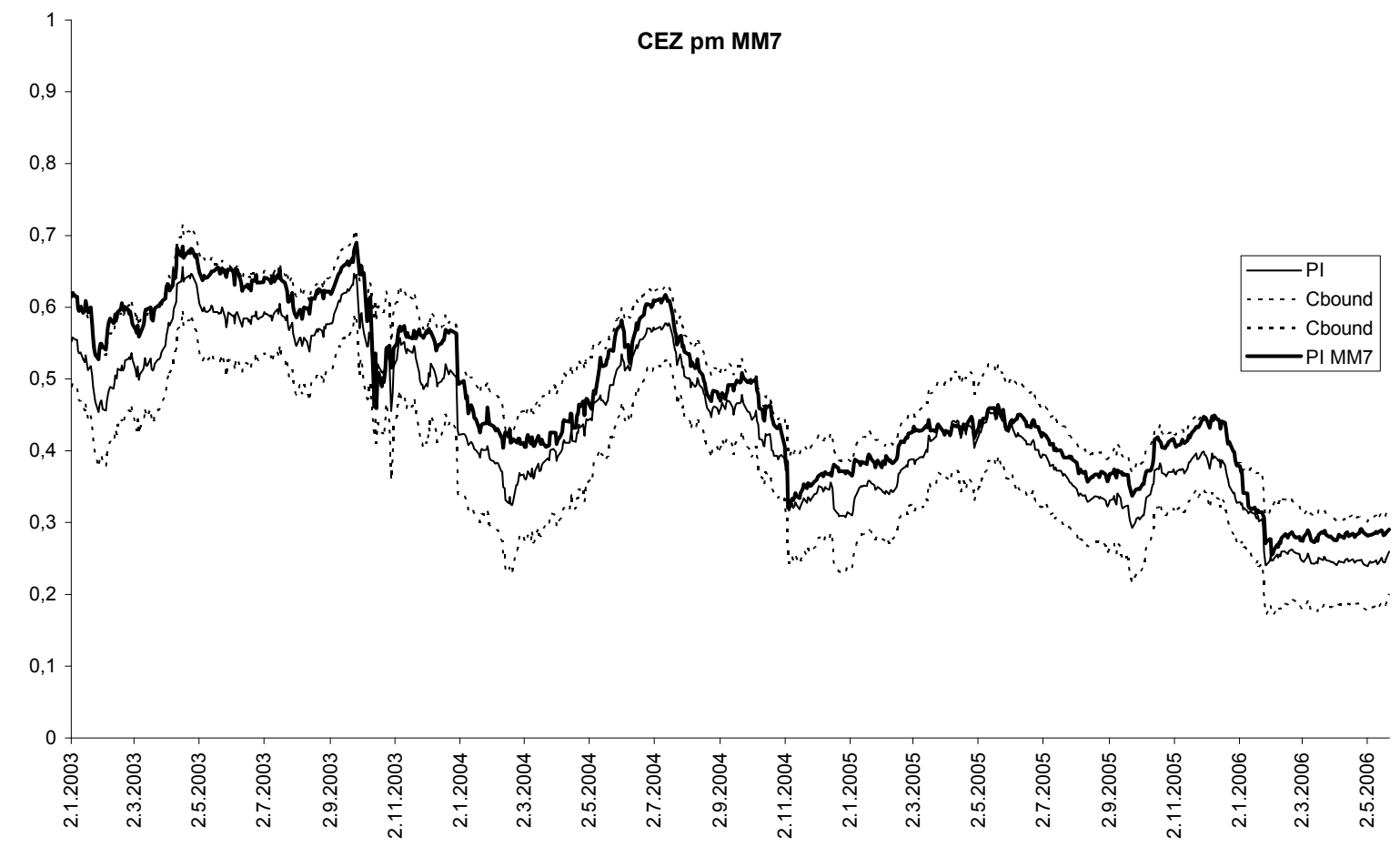

$\mathrm{y}$-axis - PIN, $\mathrm{x}$-axis - initial date of 90 day estimation period

Source: www.akcie.cz and author's computations 


\section{Figure 5}

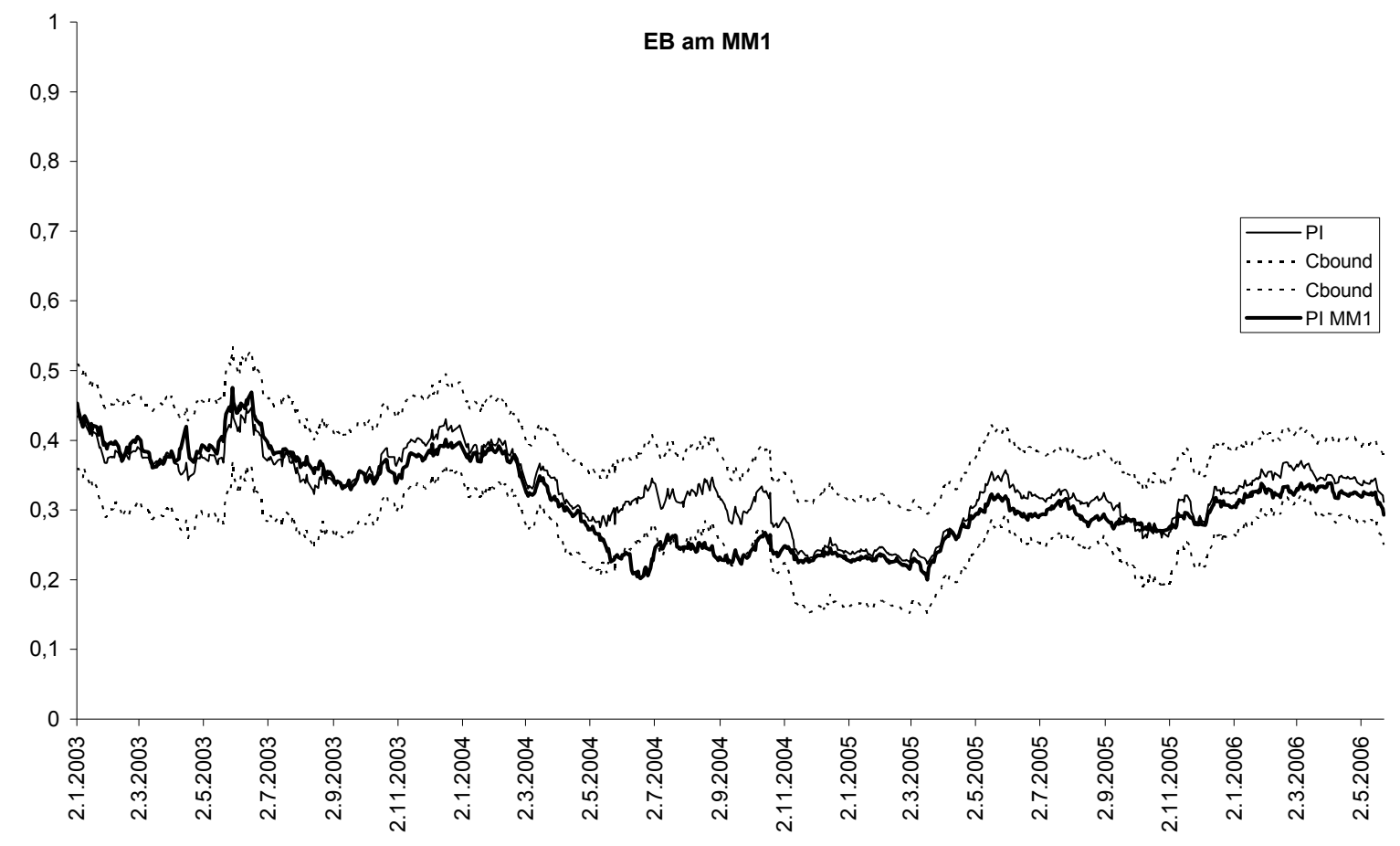

$\mathrm{y}$-axis - PIN, x-axis - initial date of 90 day estimation period

Source: www.akcie.cz and author's computations

Figure 6

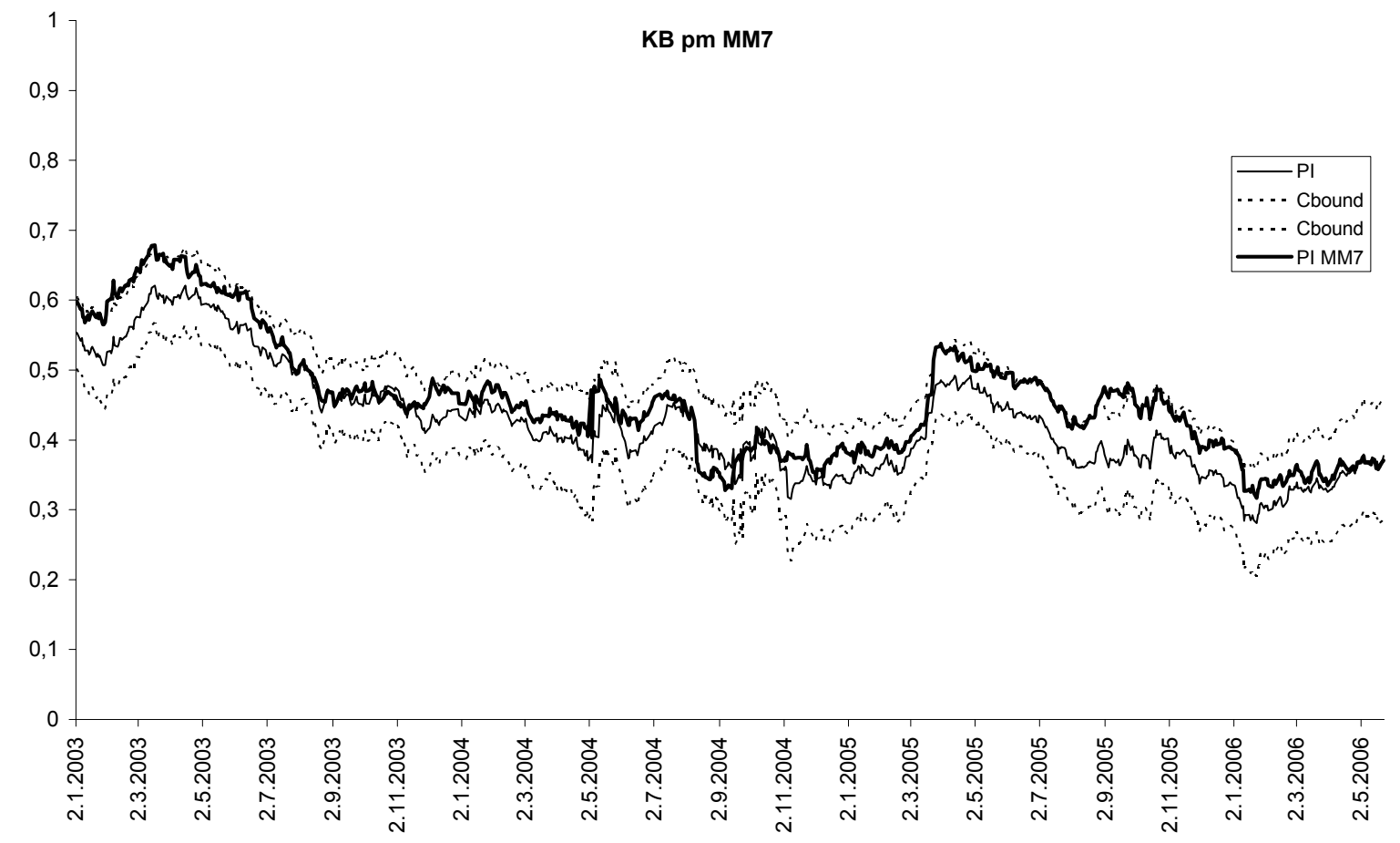

$y$-axis - PIN, x-axis - initial date of 90 day estimation period

Source: www.akcie.cz and author's computations 
Figure 7

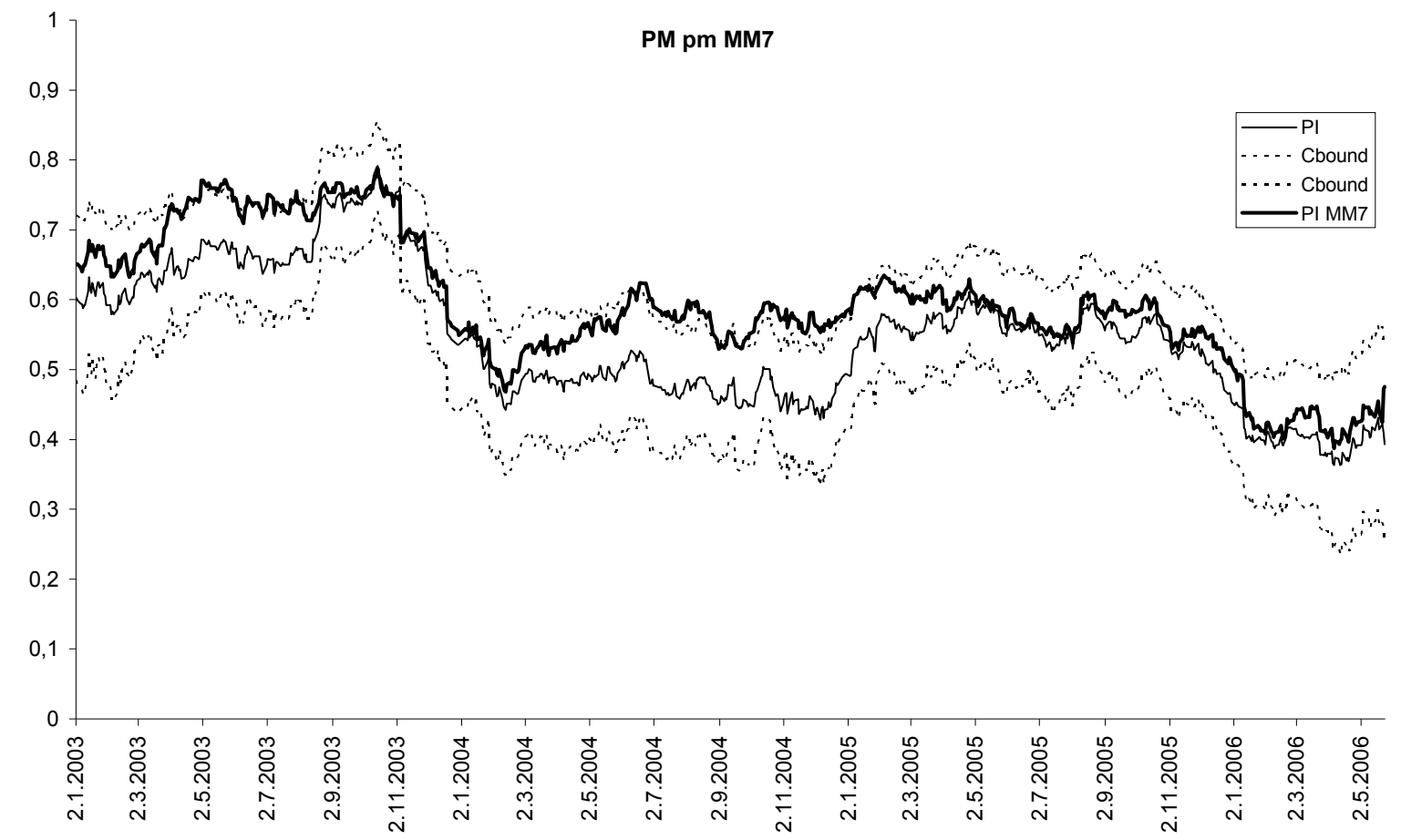

$\mathrm{y}$-axis - PIN, $\mathrm{x}$-axis - initial date of 90 day estimation period

Source: www.akcie.cz and author's computations

Figure 8

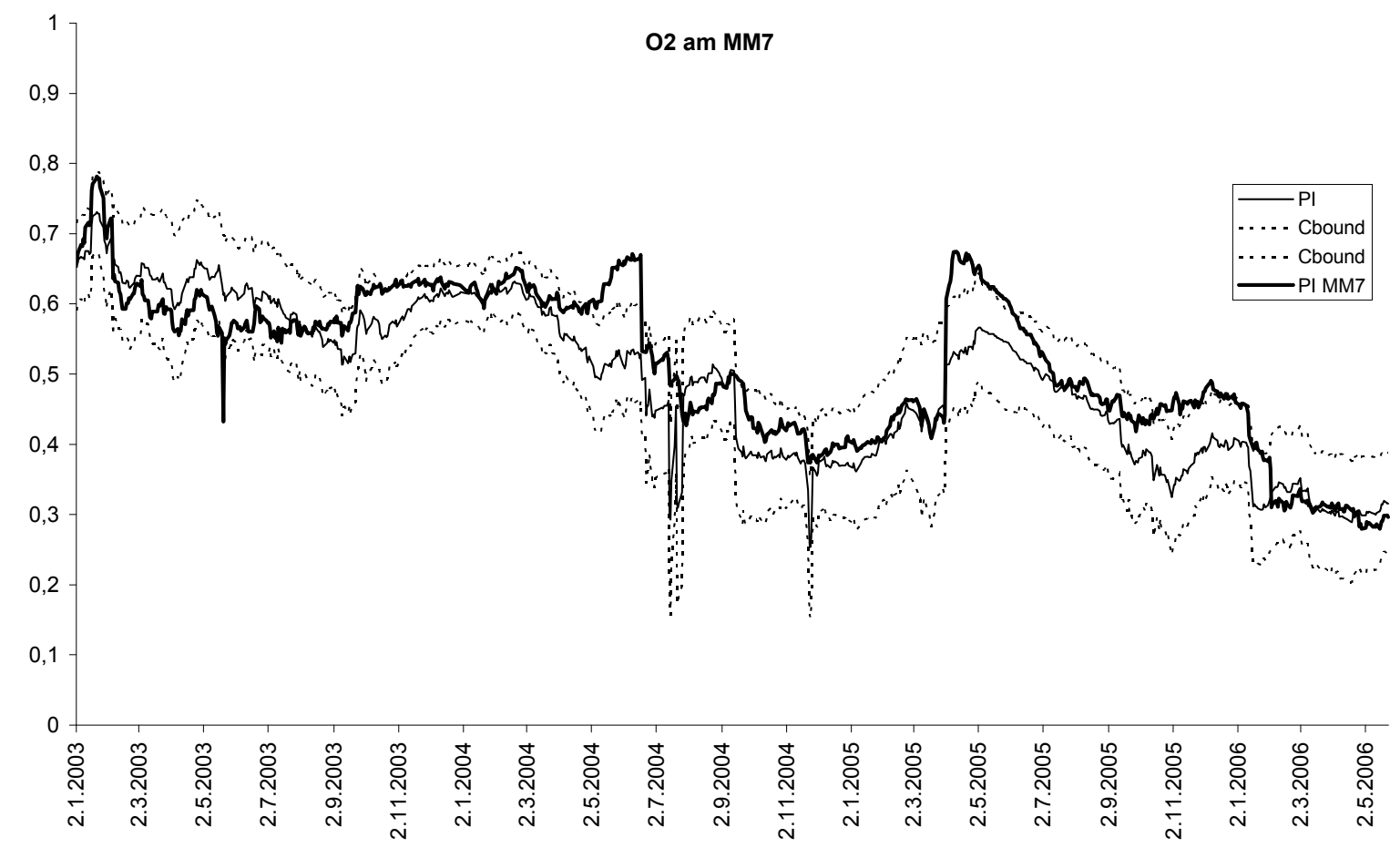

$y$-axis - PIN, x-axis - initial date of 90 day estimation period

Source: www.akcie.cz and author's computations 
Figure 9

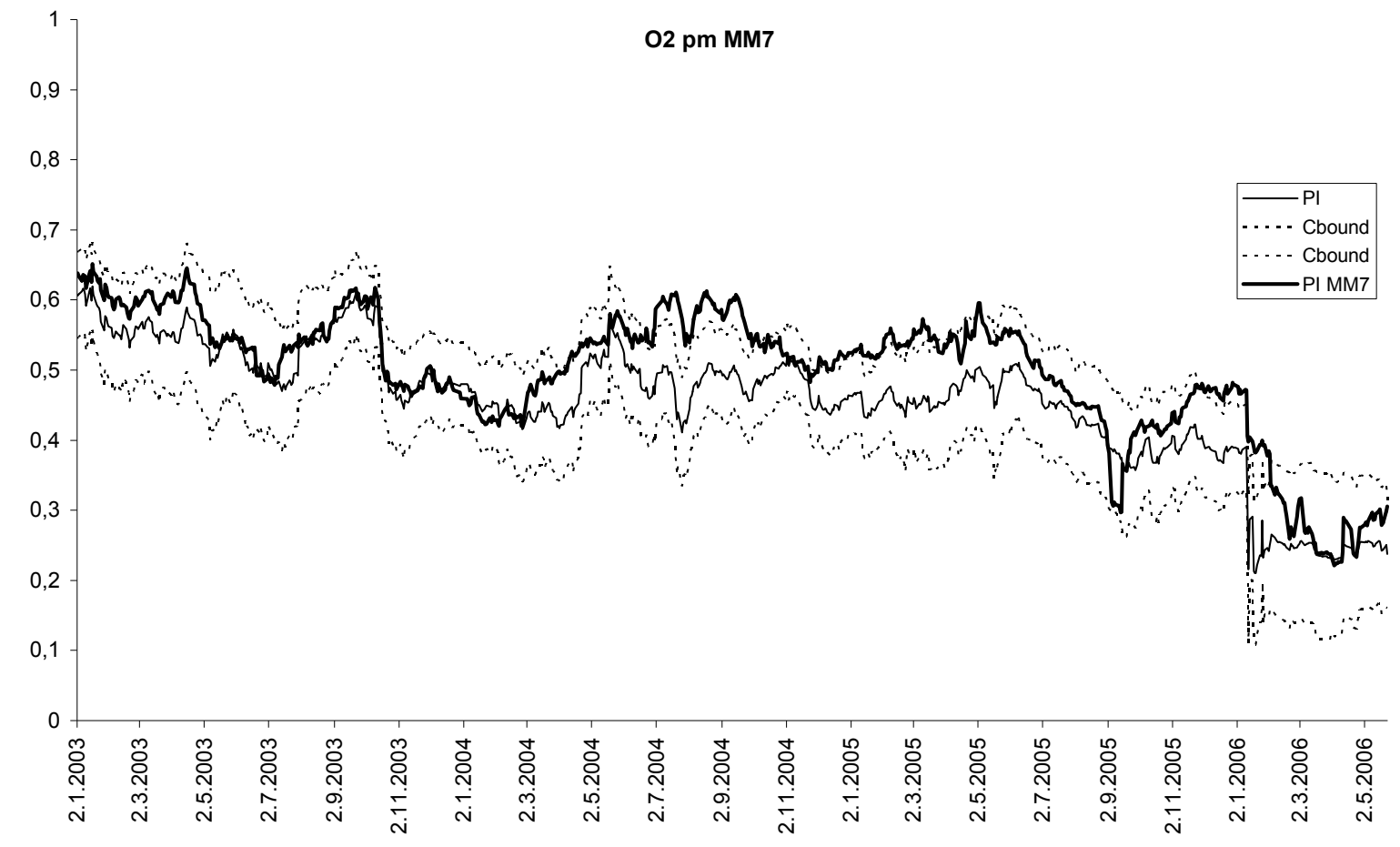

$y$-axis - PIN, $x$-axis - initial date of 90 days estimation period

Source: www.akcie.cz and author's computations

\section{Figure 10}

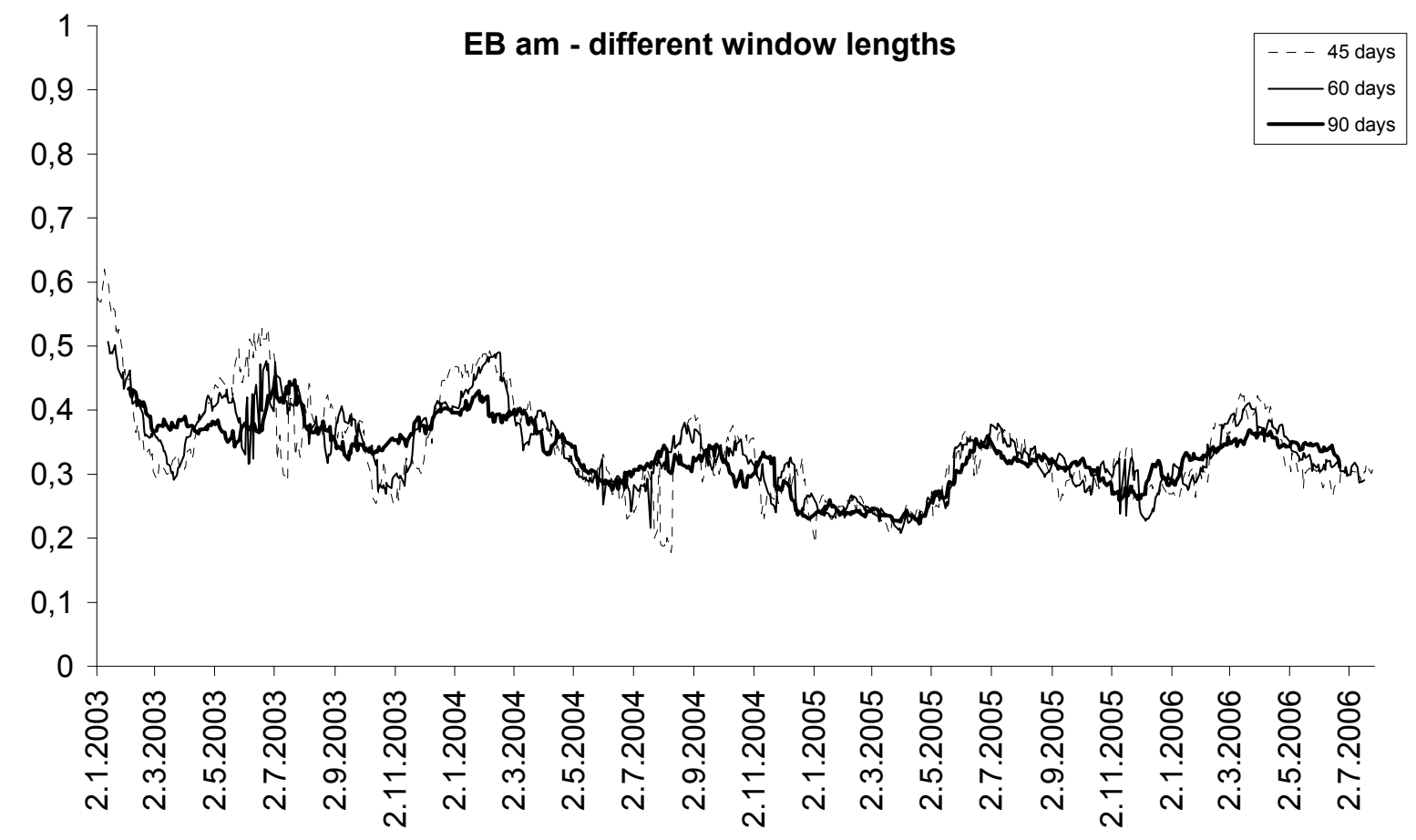

$\mathrm{y}$-axis - PIN, $\mathrm{x}$-axis - initial date of estimation period

Source: www.akcie.cz and author's computations 
Figure 11

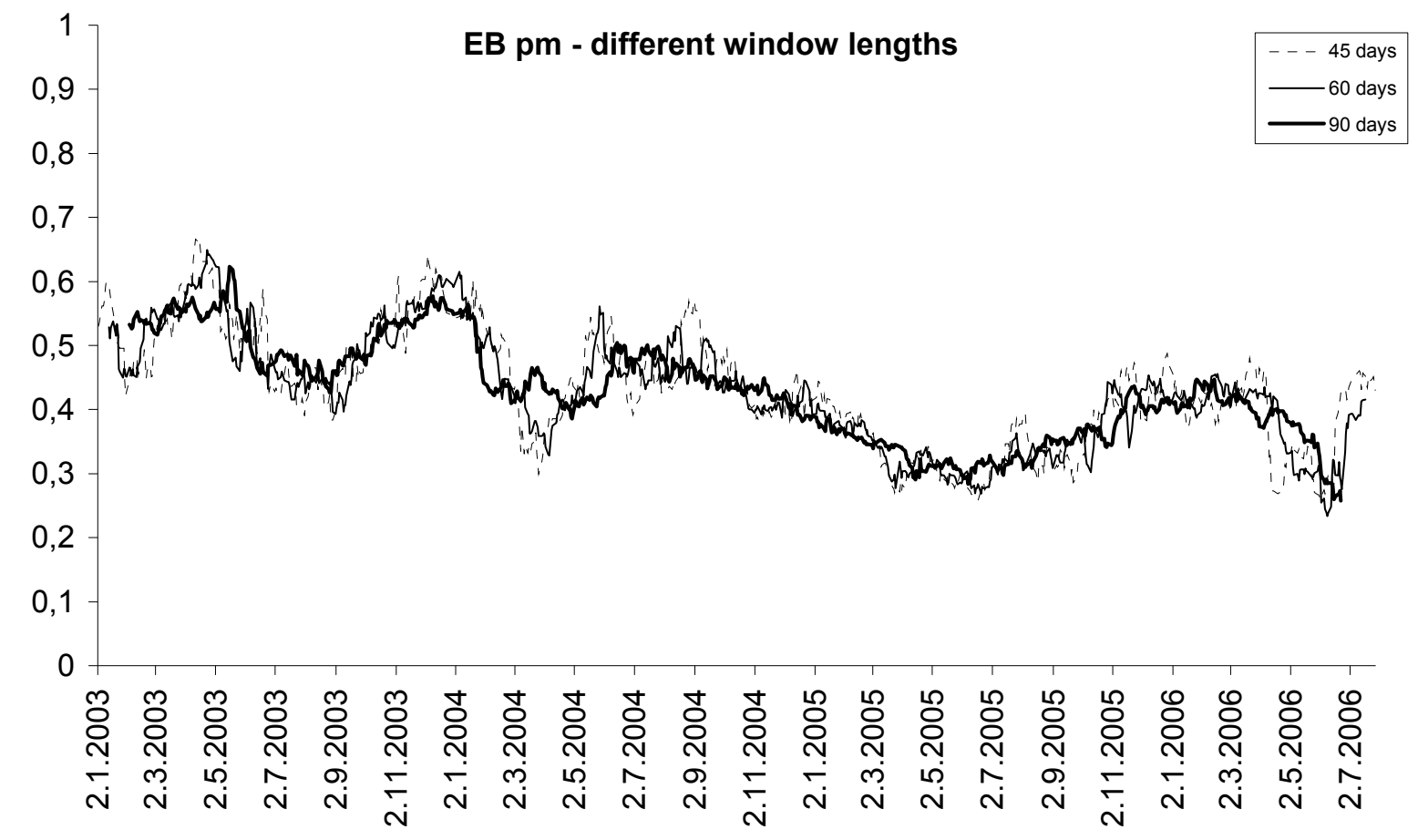

$\mathrm{y}$-axis - PIN, $\mathrm{x}$-axis - initial date of estimation period

Source: www.akcie.cz and author's computations

\section{Figure 12}

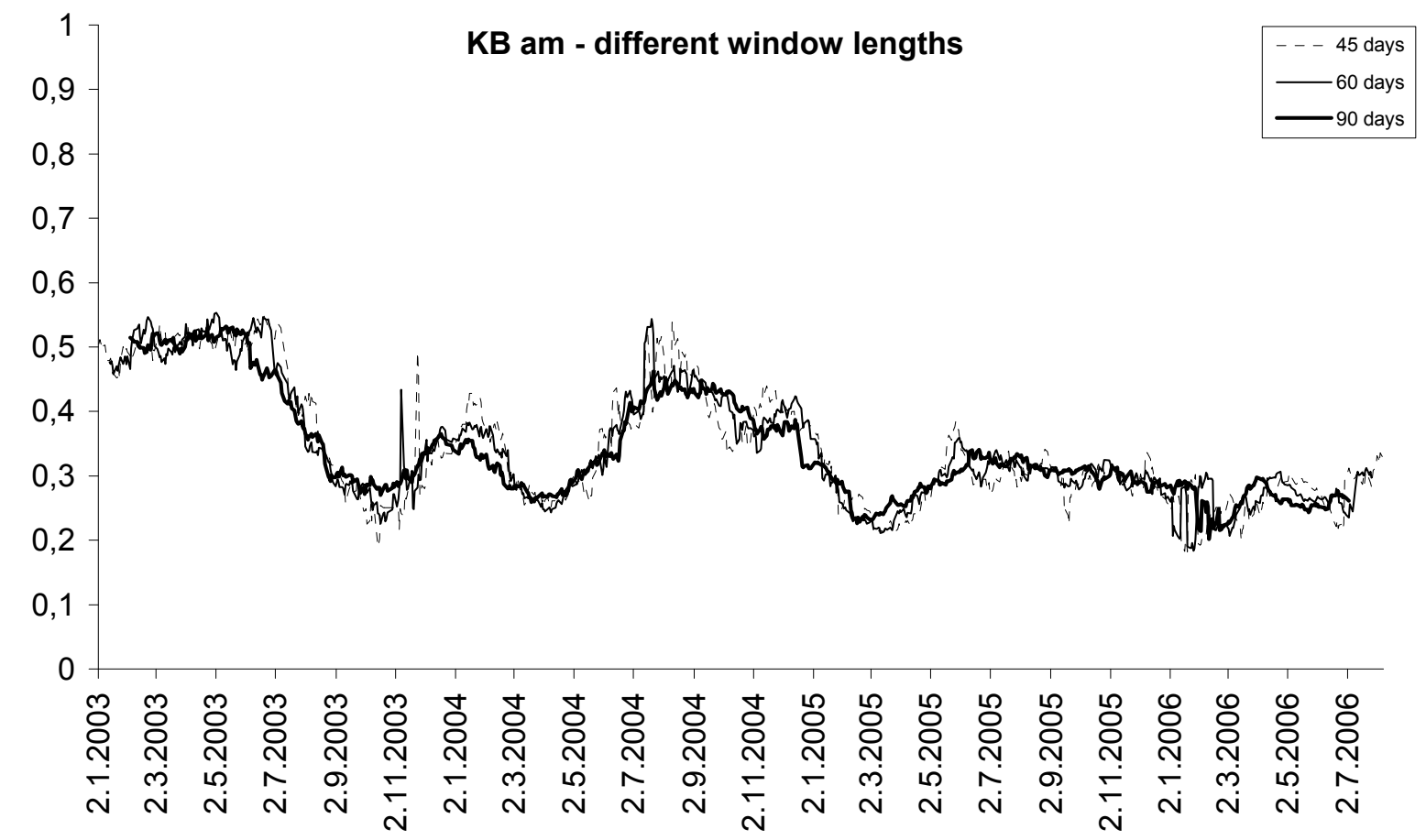

$\mathrm{y}$-axis - PIN, $\mathrm{x}$-axis - initial date of estimation period

Source: www.akcie.cz and author's computations 


\section{Figure 13}

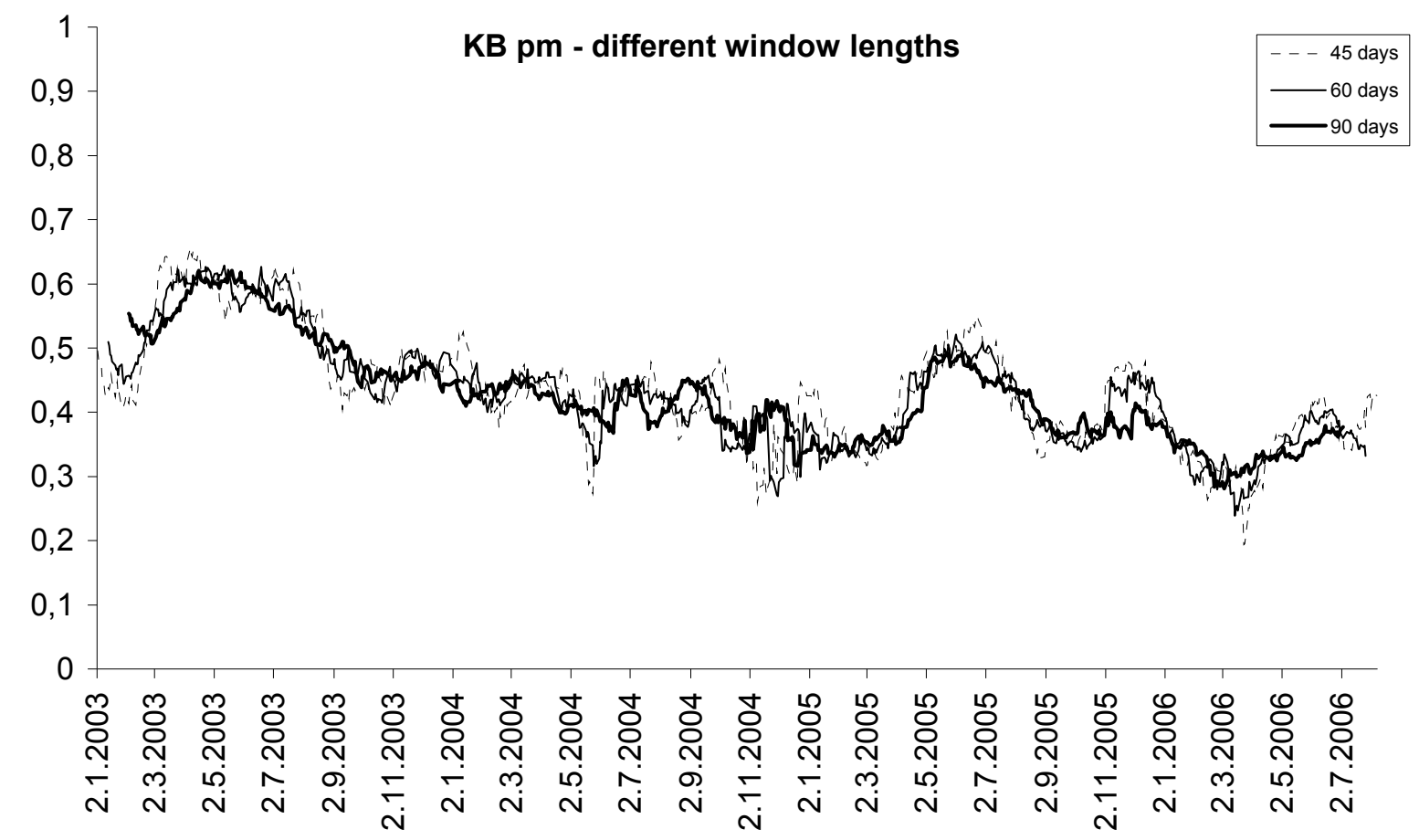

$\mathrm{y}$-axis - PIN, $\mathrm{x}$-axis - initial date of estimation period

Source: www.akcie.cz and author's computations 
Individual researchers, as well as the on-line and printed versions of the CERGE-EI Working Papers (including their dissemination) were supported from the following institutional grants:

- Center of Advanced Political Economy Research [Centrum pro pokročilá politickoekonomická studia], No. LC542, (2005-2009),

- Economic Aspects of EU and EMU Entry [Ekonomické aspekty vstupu do Evropské unie a Evropské měnové unie], No. AVOZ70850503, (2005-2010);

- Economic Impact of European Integration on the Czech Republic [Ekonomické dopady evropské integrace na ČR], No. MSM0021620846, (2005-2011);

Specific research support and/or other grants the researchers/publications benefited from are acknowledged at the beginning of the Paper.

(c) František Kopriviva, 2008.

All rights reserved. No part of this publication may be reproduced, stored in a retrieval system or transmitted in any form or by any means, electronic, mechanical or photocopying, recording, or otherwise without the prior permission of the publisher.

Published by

Charles University in Prague, Center for Economic Research and Graduate Education (CERGE) and

Economics Institute ASCR, v. v. i. (EI)

CERGE-El, Politických vězňů 7, 11121 Prague 1, tel.: +420 224005 153, Czech Republic.

Printed by CERGE-EI, Prague

Subscription: CERGE-EI homepage: http://www.cerge-ei.cz

Editors: Directors of CERGE and EI

Managing editors: Deputy Directors for Research of CERGE and EI

ISSN 1211-3298

ISBN 978-80-7343-165-5 (Univerzita Karlova. Centrum pro ekonomický výzkum

a doktorské studium)

ISBN 978-80-7344-154-8 (Národohospodářský ústav AV ČR, v. v. i.) 
CERGE-EI

P.O.BOX 882

Politických vězňů 7

11121 Praha 1

Czech Republic http://www.cerge-ei.cz 